\title{
Hydrogeochemistry of the Kasane Hot Spring, Botswana
}

\author{
Boitumelo Tebuho Mukwati, Nata T. Tafesse*, Zibisani B Bagai, Laletsang K.
}

Department of Geology, Faculty of Science, University of Botswana, Botswana

Copyright $\bigcirc 2018$ by authors, all rights reserved Authors agree that this article remains permanently open access under the terms of the Creative Commons Attribution License 4.0 International License

\begin{abstract}
The hydrogeochemistry of the Kasane hot spring in Kasane was conducted with the aim of knowing the hydrochemical nature of the spring. Kasane is situated in the most northern part of Botswana within the Chobe District. Sixteen water samples, forty-nine sediment samples and five rock samples were collected for analyses to achieve this objective. The water and sediment samples were analyzed for major cations, major anions and trace elements at the geochemistry laboratories of the University of Botswana and at the Department of Water Affairs. The physico-chemical parameters such as temperature of the water, $\mathrm{pH}, \mathrm{EC}$ and TDS were measured in-situ. Petrographic analysis of the rock thin sections was also carried out to identify the mineralogical composition of the rocks of the study area. The geology of the area is generally Karoo volcanic. Thin sections analyses revealed that the rock is basalt made up of plagioclase, clinopyroxene and opaque minerals with othopyroxene and amphibole in trace amounts. In the analyzed water samples generally based on the mean values of the chemical parameters, the cations were in the order of abundance as $\mathrm{Na}^{+}>\mathrm{Ca}^{2+}>\mathrm{Mg}^{2+}>\mathrm{K}^{+}>$ $\mathrm{Li}^{+}$and the anions were in the order of abundance as $\mathrm{Cl}^{-}>$ $\mathrm{SO}_{4}{ }^{2-}>\mathrm{HCO}_{3}{ }^{-}>\mathrm{PO}_{4}{ }^{3-}>\mathrm{Br}^{-}>\mathrm{CO}_{3}{ }^{2-}>\mathrm{NO}_{3}{ }^{-}>\mathrm{F}^{-}>\mathrm{NO}_{2}{ }^{-}$. In the analysed sediment samples the cations and anions are in the order of $\mathrm{Na}^{+}>\mathrm{Ca}^{2+}>\mathrm{K}^{+}>\mathrm{Mg}^{2+}>\mathrm{Li}^{+}$and $\mathrm{SO}_{4}{ }^{2-}>\mathrm{Cl}^{-}>\mathrm{NO}_{3}{ }^{-}>\mathrm{Fl}^{-}>\mathrm{Br}^{-}>\mathrm{NO}_{2}{ }^{-}>\mathrm{PO}_{4}{ }^{3-}$, respectively. The spring and the groundwater from the pits north of the spring are slightly alkaline to alkaline, brackish to saline and hard to very hard whereas the groundwater west of the springs, river water and the sewage water are acidic to slightly alkaline (with the exception of sample W11, which is alkaline), fresh (with the exception of sample W12, which is brackish) and soft to hard. $75 \%$ of the analyzed groundwater samples from the pits west of the hot spring show some similarities in the trend of concentration of the different constituents of the groundwater with the river water, suggesting that the groundwater is recent or derived from precipitation. The remaining 25 per cent of the groundwater samples from this part of the study area suggest that precipitation is not the sole source of groundwater and it could be derived from both precipitation and fluids of deep origin. The hot spring and the groundwater north of the hot springs are characterized by higher mineralization, and this could be attributed to the more supplement of the deep fluids that have deep origin.
\end{abstract}

This implies that the source of the spring and the groundwater north of the hot spring have a regional origin. The hot spring water and all groundwater in the studied area are not recommended for drinking purposes.

Keywords Deep Fluids, Groundwater, Hot Spring, Hydrogeochemistry, Kasane

\section{Introduction}

\subsection{General}

Water with good quality and sufficient quantity from different resources is a backbone for economic development of a country [1]. However, according to the Botswana Water Statistics report [2], Africa's water resources are threatened by the increasing population trends which result in increase in water demand by various users. In Botswana, this very precious resource is scarce due to the semi-arid climatic condition of the country which is characterized by recurrence of drought.

A spring is a concentrated discharge of groundwater appearing at the ground surface as current flowing water [3]. It may have a fairly constant or variable discharge. It may be permanent or it may be temporary. It will contain dissolved solids in the form of ions or certain dissolved gases or oils like petroleum. It may be hot or it may have a temperature that is very low.

Generally thermal springs, also referred to as hot springs, are located all over the world at special geological areas, mainly near volcanic regions. Thermal springs are by definition 'warm'; however, there is no consensus regarding the exact temperature that distinguishes a spring from a thermal spring [4]. In view of the fact that the climate of one region differs from that of another, what is 'warm' in one region may not be considered to be such elsewhere. For this reason, the definition of a thermal spring is often based on the mean annual air temperature of the specific site [4].

According to LaMoreaux and Tanner [5], thermal springs originate either from recent plutonic activity (volcanic origin) or from rainwater that percolates into the ground through permeable rocks or via conduits such as joints, faults and fracture zones in less permeable rocks 
(meteoric origin). Such water may reach considerable depths before resurfacing.

Like all natural resources, thermal springs should be managed in a sustainable manner. The availability of current scientific information on thermal springs and their properties is a pre-requisite for sound decision making regarding resource use and development. Unfortunately, there has not been any hydrogeochemical study of hot springs in Kasane. This research, which makes its objective to determine the hydrogeochemical features of the Kasane hot spring and the groundwater in its surrounding areas, and determine their suitability for drinking purpose, presents, for the first time, information on thermal springs located in the northern part of the country at Kasane in the Chobe District.

\subsection{Description of the Study Area}

\subsubsection{Location}

The study area is situated in the northern part of Botswana at Kasane in the Chobe District. Chobe District $\left(22,560 \mathrm{~km}^{2}\right)$ is one of the smallest districts in Botswana and has an international setting. It is where Botswana meets Namibia, Zimbabwe and Zambia. Kasane is a few kilometers from the Chobe River's confluence with the Zambezi River and lies within the lines of longitude of $24^{\circ}$ and $26^{\circ} \mathrm{E}$, and latitude of $17^{\circ}$ and $19^{\circ} \mathrm{S}$ (Fig 1).

\subsubsection{Topography and Drainage}

The Chobe district in general is made up of a relatively featureless central plateau and floodplains in the north and west of the district. The whole study area drains toward the Chobe River. The Chobe River rises as the Cuando in the highlands of Angola. When it crosses into Botswana, it becomes the Linyanti, at Parakarungu it becomes the Itenge, and at Ngoma Gate it becomes the Chobe River. Finally, it joins the Zambezi at Kazungula after which they hurtle together over Victoria Falls.

The studied area consists of only one hot spring issue from the alluvial sediments in the floodplain. According to the information from the elder peoples in the community, there were other hot springs in the area. However, at present these hot springs do not exist anymore, and nobody knows when they disappeared or where the exact positions of the springs were.

The climate in Kasane is referred to as a local steppe climate or a hot semi-arid steppe climate. In a year, the average rainfall is $643 \mathrm{~mm}$. Generally, the annual rainfall varies between $550 \mathrm{~mm}$ and $650 \mathrm{~mm}$ being the highest in the country and the least variable. Over the course of a year, the temperature typically varies from $9{ }^{\circ} \mathrm{C}$ to $35^{\circ} \mathrm{C}$.

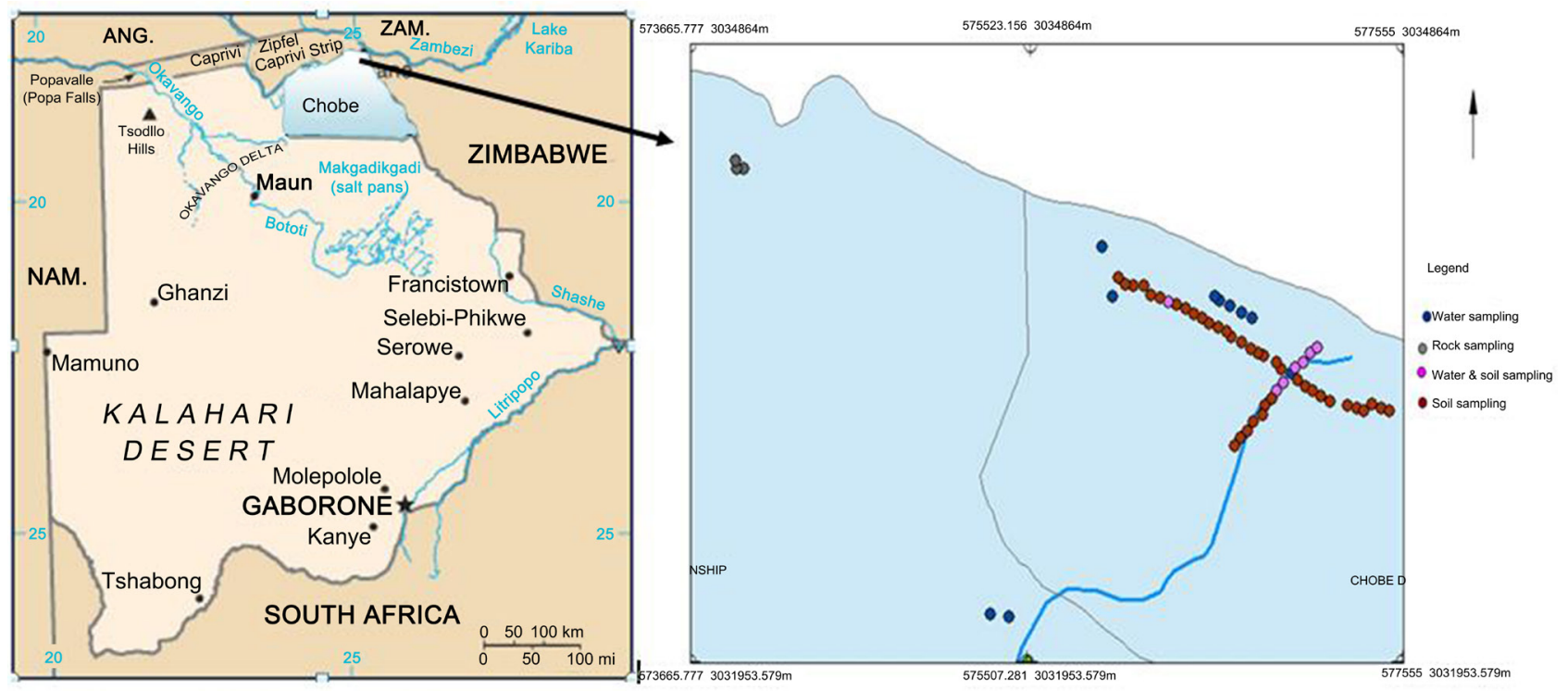

Figure 1. Location of the study area. 


\subsubsection{Geology of the Study Area}

\subsubsection{Local Geology}

The local geology is comprised of the Karoo Supergroup rocks. The Kalahari Basin is amongst the several contemporaneous basins in southern Africa which covers an extensive area in Botswana (Fig 2). The Kalahari basin is contiguous to the Mid-Zambezi basin which is located in the northwestern part of Zimbabwe. The boundary between the two basins is not well defined. The top most geologic unit in the Kalahari Basin is the basalt of the Stormberg Lava Group [6]. Based on the stratigraphic section obtained in the eastern part of the Kalahari basin, the Stormberg Lava Group is underlain by the sandstone of Ntane Formation which in turn overly the Mosolotsane Formation which is essential made up of arenaceous sediments of fluvial origin. Below the Mosolotsane Formation is the Thabala Formation which conformably overlies the Tlapana Formation. The Tlapana Formation is comprised of mudstones, carbonaceous shales and coal seams. It overlies the Mea arkose Formation which is generally composed of pebbly sandstones and conglomerates [7].

The adjacent Mid-Zambezi basin contains a thick basaltic rock at the top which belong to the Batoka Formation. The basalt is underlain by the Forest Sandstone Formation comparable to the Ntane Formation. Below the Forest Sandstone occurs the pebbly arkose and fine red marly sandstone with ripple marked flagstone at the bottom. This unit is a correlative of the Mosolotsane Formation [6]. It is important to note that the study area (Kasane) is located mid-way between the Kalahari and Mid-Zambezi basins (Fig 2). Though the area is considered to be part of the Kalahari basin, there is no lithostratigraphic data from the area to confirm the stratigraphic column of the Karoo sequence in the area since there are no boreholes drilled in the area or in the vicinity of the area in Botswana.

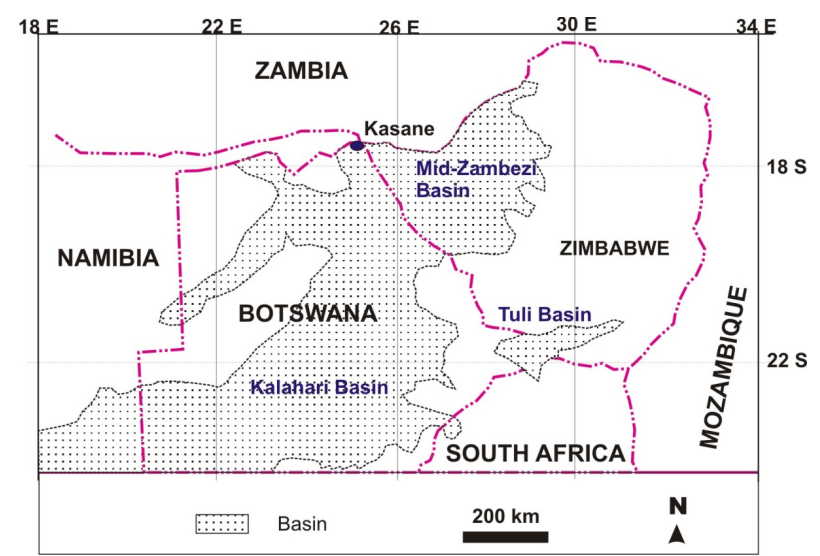

Figure 2 Map showing the Karoo basins in the study area (modified from Johnson et al., 1996).

\section{Methodology}

In order to determine the hydrogeochemistry of the
Kasane hot spring, representative water, sediment and rock samples were collected during the rainy season. Analyses of the water and sediment samples were carried out both in the geochemistry laboratory of the University of Botswana and in the laboratory of the Department of Water Affairs of Botswana. Cations and trace elements of the water and sediment samples were analysed in the geochemistry laboratory of the University of Botswana. Anions of the water samples were analysed in the laboratory of the Department of Water Affairs of Botswana. Anions of the sediments samples were analysed in the geochemistry laboratory of the University of Botswana. Rock samples were characterized by studying thin-sections at the transmitted light microscope.

\subsection{Data Collection}

Sixteen (16) water samples, forty nine (49) sediment samples and five (5) rock samples were collected from different sites of the studied area.

The water samples were collected from the hot spring, sewage ponds, the river and the pits: one from hot spring, two from sewage ponds, one from the nearby river water and 12 from the drilled pits. The pits, which were drilled for sediment sampling purposes, were drilled in different directions and at different intervals from the spring; because of this reason, with the exception of the hot spring sample all the water samples from the pits were obtained from the same points where sediment sampling was done. The pits had a dimension of $30 \mathrm{~cm}$ by $30 \mathrm{~cm}$ and depth of $50 \mathrm{~cm}$. One kilogram $(\mathrm{kg})$ sediment samples were collected from each pit using a plastic bag. The positions and altitudes of the pits were determined using Global Positioning System (GPS).

The sediments were obtained from all directions (north, south, east and west) of the spring at a distance of an interval of $50 \mathrm{~m}$ with the spring as the point of origin. Since the pits east and south of the hot spring were dry and did not yield any water the water samples were obtained only from north and west of the of spring. The two sewage ponds are located in the upstream side of the hot spring, while the river is located in the downstream side of the spring. The river is of a perennial type.

The water samples were collected in one litre Polyethylene terephthalate bottles after filtered them through $0.45-\mu \mathrm{m}$ cellulose filters. Prior to sampling the bottles were rinsed with samples to be collected. In the field in situ measurements of the water temperature, $\mathrm{pH}$, EC, and TDS were conducted using digital multi-parameter analyser model Hanna. The positions and altitudes of the sampling points (locations) were also determined using Global Positioning System (GPS).

Representative rock samples were also collected during the field work from the outcrops. The positions and altitudes of the sampling points (location) determined using Global Positioning System (GPS). Thin-sections of 
the rocks samples were prepared in the University of Botswana at the cutting and polishing laboratory of the Department of Geology for petrographic investigation.

\subsection{Data Analyses}

\section{Water samples}

The water samples were analyzed for calcium $\left(\mathrm{Ca}^{2+}\right)$, magnesium $\left(\mathrm{Mg}^{2+}\right)$, potassium $\left(\mathrm{K}^{+}\right)$, sodium $\left(\mathrm{Na}^{+}\right)$, lithium $\left(\mathrm{Li}^{+}\right)$, carbonate $\left(\mathrm{CO}_{3}{ }^{2-}\right)$, bicarbonate $\left(\mathrm{HCO}_{3}^{-}\right)$, chloride $\left(\mathrm{Cl}^{-}\right)$, sulfate $\left(\mathrm{SO}_{4}{ }^{2-}\right)$, nitrate $\left(\mathrm{NO}_{3}{ }^{-}\right)$, fluoride $\left(\mathrm{F}^{-}\right)$, phosphate $\left(\mathrm{PO}_{4}{ }^{3-}\right)$, nitrite $\left(\mathrm{NO}_{2}{ }^{-}\right)$and bromine $\left(\mathrm{Br}^{-}\right)$. The trace element that were analysed in the water samples were arsenic (As), barium $(\mathrm{Ba})$, cadmium $(\mathrm{Cd})$, cobalt $(\mathrm{Co})$, chromium $(\mathrm{Cr})$, copper $(\mathrm{Cu})$, iron $(\mathrm{Fe})$, manganese $(\mathrm{Mn})$, lead $(\mathrm{Pb})$, nickel $(\mathrm{Ni})$ and zinc $(\mathrm{Zn})$. The water from sewage ponds, river and pits were analyzed for comparison with hot spring water.

All cations and trace elements were analysed using ICP-MS. The method applied for the analysis of anions was ISO 10304 using the ion chromatography. The alkalinity and hardness of water samples were determined using AquaChem software.

In the water analyses, for analytical precision of measured samples, charge balance was calculated using the following equation:

Where, E.N $(\%)=$

$$
=\left[\frac{(\text { Sum cations }- \text { Sum anions })}{(\text { Sum cations }+ \text { Sum anions })}\right] * 100
$$

All the measurements are in milli equivalents per litre.

Simple descriptive statistical method was utilized for the analyses of the groundwater chemistry data. Besides, AquaChem software was used to process water geochemical data. Piper diagram was prepared to represent and compare water quality data in the area. Gibbs diagram was also used to see the relationship of water composition and aquifer lithological characteristics.

\section{Sediments samples}

The soil samples were analyzed for calcium $\left(\mathrm{Ca}^{2+}\right)$, magnesium $\left(\mathrm{Mg}^{2+}\right)$, potassium $\left(\mathrm{K}^{+}\right)$, sodium $\left(\mathrm{Na}^{+}\right)$, and lithium $\left(\mathrm{Li}^{+}\right)$, chloride $\left(\mathrm{Cl}^{-}\right)$, sulfate $\left(\mathrm{SO}_{4}{ }^{2-}\right)$, nitrate $\left(\mathrm{NO}_{3}{ }^{-}\right)$, fluoride $\left(\mathrm{F}^{-}\right)$, phosphate $\left(\mathrm{PO}_{4}{ }^{3-}\right)$, nitrite $\left(\mathrm{NO}_{2}{ }^{-}\right)$and bromine $\left.(\mathrm{Br})^{-}\right)$. The trace element that were analysed in the soil samples were arsenic (As), barium (Ba), cadmium (Cd), Cobalt $(\mathrm{Co})$, chromium $(\mathrm{Cr})$, copper $(\mathrm{Cu})$, iron $(\mathrm{Fe})$, manganese $(\mathrm{Mn})$, lead $(\mathrm{Pb})$, nickel $(\mathrm{Ni})$ and zinc $(\mathrm{Zn})$. Simple descriptive statistical method was used for the analyses of the soil chemistry data too.

\section{Rock samples}

The rock samples were preliminarily characterized by studying the hand specimen. Thereafter, thin-sections of the rock samples were observed for minerals at the transmitted light microscope using Nikon Eclipse 50i POL microscope at the petrological laboratory of the Department of Geology in the University of Botswana in order to establish the relationship between the geology and the chemistry of the water in the study area.

\section{Results and Discussions}

\subsection{Results}

\subsubsection{Physico-chemical Parameters}

The water is acidic to alkaline and soft to very hard $\mathrm{pH}$ ranges from 6.33 to 9.12 with an average of 7.27 . The maximum value of $\mathrm{pH}$ was measured $750 \mathrm{~m}$ west of the spring and minimum was measured in the center of the river. Electrical conductivity and total dissolved solids range from $82 \mu \mathrm{S} / \mathrm{cm}$ to $22320 \mu \mathrm{S} / \mathrm{cm}$ and $36.72 \mathrm{mg} / \mathrm{l}$ to $14476.92 \mathrm{mg} / \mathrm{l}$ with a mean value of $5172.75 \mu \mathrm{S} / \mathrm{cm}$ and $3140.72 \mathrm{mg} / \mathrm{l}$, respectively. The highest electrical conductivity value is $22320 \mu \mathrm{S} / \mathrm{cm}$ measured $50 \mathrm{~m}$ north of the spring. From north side of the spring all the measured electrical conductivity values are above $10000 \mu \mathrm{S} / \mathrm{cm}$. The measured electrical conductivity values west of the spring and at the sewage have low values mostly below 1500 $\mu \mathrm{S} / \mathrm{cm}$. The temperature of the water samples was recorded between $25{ }^{\circ} \mathrm{C}$ and $49.7{ }^{\circ} \mathrm{C}$ with an average value of $28.99{ }^{\circ} \mathrm{C}$. The maximum temperature was measured in the spring and the lowest was $1197.5 \mathrm{~m}$ west of the spring.

\subsubsection{Hardness and Alkalinity}

The hardness of the water in the study area varies from soft to very hard. All the water samples north of the hot spring reveal that the water is very hard to hard whereas the water samples west of the hot spring indicates that water is soft. The sewage water from upstream side, which is south of the hot spring, and the river water from downstream side are both soft water.

The alkalinity of the water samples range from 31.58 to $446.92 \mathrm{mg} / \mathrm{l}$ of $\mathrm{CaCO}_{3}$. Very high values are observed north of the hot springs and in one of the sewage sample. The result indicates that all the waters of the studied area are less susceptible to acidification.

\subsubsection{Water Type}

The chemical analysis results of the water samples from the study area are plotted in Piper diagram using Aquachem software (Fig 3). Accordingly, with the exception of the sewage water and one water sample from west of the hot spring, three major water types are recognized in the studied area: $\mathrm{Ca}-\mathrm{Mg}-\mathrm{Na}-\mathrm{HCO}_{3}$, $\mathrm{Na}-\mathrm{Cl}-\mathrm{SO}_{4}$, and $\mathrm{Na}-\mathrm{SO}_{4}-\mathrm{Cl}$; constituting $38 \%, 31 \%$, and $13 \%$ of the total water samples, respectively. The two sewage water samples are $\mathrm{Na}-\mathrm{HCO}_{3}-\mathrm{Cl}$ and 
$\mathrm{Na}-\mathrm{Cl}-\mathrm{HCO}_{3}-\mathrm{SO}_{4}$ types, while one sample from west of the hot spring shows $\mathrm{Ca}-\mathrm{Mg}-\mathrm{HCO}_{3}$.

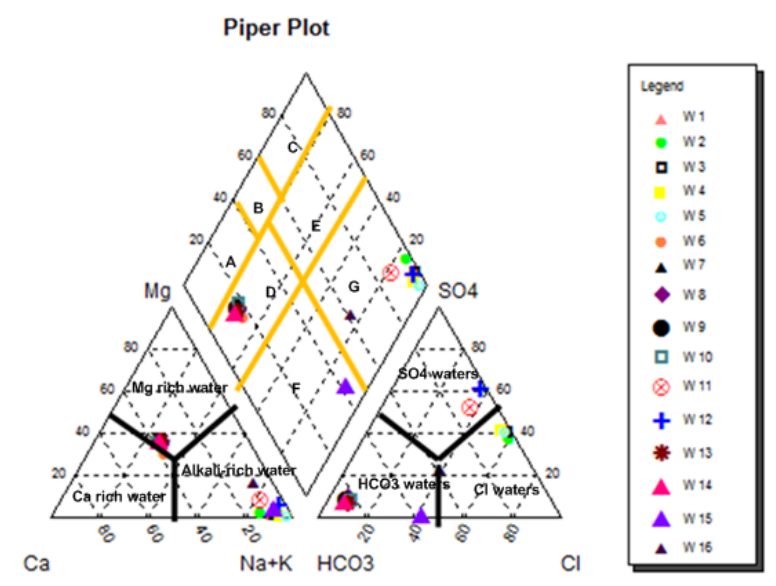

Figure 3. Piper plot for the water samples

\subsubsection{Major Ions Compositions}

The summarized results of the chemical composition of the analyzed water samples are given in Table 1 below.

The dominant cations in the water samples are sodium and calcium. The concentration of $\mathrm{Na}^{+}$ranges from 3.491 $\mathrm{mg} / \mathrm{l}$ to $4308 \mathrm{mg} / \mathrm{l}$ having a mean value of $1042.12 \mathrm{mg} / \mathrm{l}$. $\mathrm{K}^{+}$ranges from $1.493 \mathrm{mg} / \mathrm{l}$ to $25.42 \mathrm{mg} / 1$ with a mean value of $8.869 \mathrm{mg} / \mathrm{l}$. Ca ${ }^{2+}$ ranges from $5.01 \mathrm{mg} / \mathrm{l}$ to 349.8 $\mathrm{mg} / \mathrm{l}$ with a mean value of $70.4709 \mathrm{mg} / \mathrm{l}$ while $\mathrm{Mg}^{2+}$ ranges from $2.791 \mathrm{mg} / 1$ to $41.72 \mathrm{mg} / \mathrm{l}$ with a mean value of $10.869 \mathrm{mg} / \mathrm{l}$. Cation content indicates that $43.75 \%$ of the water samples follows the following trend; $\mathrm{Ca}^{2+}>\mathrm{Na}^{+}>$ $\mathrm{Mg}^{2+}>\mathrm{K}^{+}>\mathrm{Li}^{+}$. The remaining samples follow 5 different trends; $18.75 \%$ shows $\mathrm{Na}^{+}>\mathrm{Ca}^{2+}>\mathrm{K}^{+}>\mathrm{Mg}^{2+}>\mathrm{Li}^{+}$; $18.75 \%$ of the samples shows $\mathrm{Na}^{+}>\mathrm{Ca}^{2+}>\mathrm{Mg}^{2+}>\mathrm{K}^{+}>$ $\mathrm{Li}^{+}$; and, the last 3 samples which take up $6.25 \%$ of the total number of samples are each unique and follow the following trends $\mathrm{Na}^{+}>\mathrm{Mg}^{2+}>\mathrm{Ca}^{2+}>\mathrm{K}^{+}>\mathrm{Li}^{+}, \mathrm{Na}^{+}>\mathrm{K}^{+}>$
$\mathrm{Ca}^{2+}>\mathrm{Mg}^{2+}>\mathrm{Li}^{+}$and $\mathrm{Na}^{+}>\mathrm{K}^{+}>\mathrm{Mg}^{2+}>\mathrm{Ca}^{2+}>\mathrm{Li}^{+}$. Generally, based on the mean values of the chemical parameters, the cations were in the order of abundance as $\mathrm{Na}^{+}>\mathrm{Ca}^{2+}>\mathrm{Mg}^{2+}>\mathrm{K}^{+}>\mathrm{Li}^{+}$.

Among anions, $\mathrm{HCO}_{3}{ }^{-}$ranges from $38.5 \mathrm{mg} / 1$ to 544.9 $\mathrm{mg} / \mathrm{l}$ with mean value of $167.044 \mathrm{mg} / \mathrm{l}$ while $\mathrm{CO}_{3}{ }^{2-}$ ranges from $0 \mathrm{mg} / \mathrm{l}$ to $25.2 \mathrm{mg} / \mathrm{l}$ with mean value of $2.413 \mathrm{mg} / 1$. The concentration of $\mathrm{SO}_{4}{ }^{2-}$ ranges from $2.39 \mathrm{mg} / \mathrm{l}$ to $6369.31 \mathrm{mg} / 1$ with a mean value of $1469.98 \mathrm{mg} / 1$ while $\mathrm{Cl}^{-}$ ranges from $1.93 \mathrm{mg} / \mathrm{l}$ to $7570.65 \mathrm{mg} / \mathrm{l}$ with mean value of $1505.72 \mathrm{mg} / \mathrm{l}$. The concentration of $\mathrm{NO}_{3}{ }^{-}$ranges from 0 $\mathrm{mg} / \mathrm{l}$ to $20.23 \mathrm{mg} / \mathrm{l}$ with mean value of $2.4 \mathrm{mg} / \mathrm{l}$ while $\mathrm{NO}_{2}{ }^{-}$ranges from $0 \mathrm{mg} / \mathrm{l}$ to $0.05 \mathrm{mg} / \mathrm{l}$ with mean value of $0.009 \mathrm{mg} / \mathrm{l}$. $\mathrm{F}^{-}$ranges from $0.02 \mathrm{mg} / \mathrm{l}$ to $5.36 \mathrm{mg} / \mathrm{l}$ with mean value of $1.354 \mathrm{mg} / \mathrm{l} . \mathrm{PO}_{4}{ }^{3-}$ concentration ranges from $0 \mathrm{mg} / \mathrm{l}$ to $45.6 \mathrm{mg} / \mathrm{l}$ with mean value of $3.55 \mathrm{mg} / \mathrm{l}$. Generally based on the mean values of the chemical parameters, the anions were in the order of abundance as $\mathrm{Cl}^{-}>\mathrm{SO}_{4}{ }^{2-}>\mathrm{HCO}_{3}{ }^{-}>\mathrm{PO}_{4}{ }^{3-}>\mathrm{Br}^{-}>\mathrm{CO}_{3}{ }^{2-}>\mathrm{NO}_{3}{ }^{-}>\mathrm{F}^{-}>$ $\mathrm{NO}_{2}^{-}$.

There is a variation of chloride concentrations of the water samples with the lowest concentration observed from the river and the highest observed $50 \mathrm{~m}$ north of the spring. The chloride concentration increases towards the spring from both the north and west directions. However, the concentration is lowest in the river sample.

The samples obtained from the spring and from north of the spring measured the highest levels of sulphate compared to the rest of the samples. These concentrations were all above $2000 \mathrm{mg} / \mathrm{l}$. Lower concentration levels were obtained mostly from samples west of the spring.

The highest nitrate level was from the sewage water sample. Generally, the nitrate concentration decreased towards the spring from the directions which were analyzed for nitrates (west and north). 
Table 1. Summarized results of the analyzed water samples (mg/l).

\begin{tabular}{|c|c|c|c|c|c|c|c|c|c|c|c|c|c|c|c|}
\hline ID & Type/direction* & $\mathrm{Cl}^{-}$ & $\mathrm{SO}_{4}{ }^{2-}$ & $\mathrm{NO}_{3}^{-}$ & $\mathrm{F}^{-}$ & $\mathrm{CO}_{3}^{2-}$ & $\mathrm{HCO}_{3}^{-}$ & $\mathrm{NO}_{2}^{-}$ & $\mathrm{PO}_{4}^{3-}$ & $\mathrm{Br}^{-}$ & $\mathrm{Ca}^{2+}$ & $\mathrm{K}^{+}$ & $\mathrm{Li}^{+}$ & $\mathrm{Mg}^{2+}$ & $\mathrm{Na}^{+}$ \\
\hline W1 & Hot spring & 3452.21 & 3398.47 & 1.05 & 2.96 & 0 & 110.4 & 0 & 0 & 7.95 & 151.74 & 15.664 & 0.4759 & 12.94 & 1983.6 \\
\hline W2 & $50 \mathrm{~m} \mathrm{~N}$ & 7570.65 & 6369.31 & 0 & 3.63 & 0 & 544.9 & 0 & 0 & 15.43 & 349.8 & 25.42 & 0.6286 & 36.22 & 2649 \\
\hline W3 & $100 \mathrm{~m} \mathrm{~N}$ & 5321.91 & 5047.33 & 1.87 & 3.03 & 0 & 316.2 & 0 & 0 & 10.8 & 294.81 & 19.868 & 0.5451 & 24.92 & 4308 \\
\hline W4 & $150 \mathrm{~m} \mathrm{~N}$ & 3321.67 & 3321.26 & 0.3 & 5.11 & 0 & 406.4 & 0 & 0 & 7.78 & 154.82 & 15.96 & 0.4307 & 9.989 & 3105 \\
\hline W5 & $200 \mathrm{~m} \mathrm{~N}$ & 3069.53 & 2921.92 & 6.97 & 5.36 & 13.4 & 285.6 & 0 & 0 & 6.97 & 67.34 & 16.694 & 0.4296 & 6.756 & 2882 \\
\hline W6 & $300 \mathrm{~m} \mathrm{~W}$ & 2.43 & 3.22 & 0.42 & 0.02 & 0 & 40.7 & 0.05 & 0 & 0.004 & 7.287 & 2.052 & 0.0021 & 3.483 & 5.847 \\
\hline W7 & $350 \mathrm{~m} \mathrm{~W}$ & 2.21 & 3.09 & 0.46 & 0.04 & 0 & 40.9 & 0.03 & 0 & 0.02 & 5.812 & 1.694 & 0.0015 & 3.208 & 3.82 \\
\hline W8 & $400 \mathrm{~m} \mathrm{~W}$ & 2.22 & 3.44 & 0.35 & 0.03 & 0 & 40.5 & 0 & 0 & 0.001 & 5.554 & 1.493 & 0.0015 & 3.085 & 3.966 \\
\hline W9 & $500 \mathrm{~m} \mathrm{~W}$ & 2.04 & 2.92 & 0.37 & 0.03 & 0 & 38.5 & 0.03 & 0 & 0 & 5.484 & 1.615 & 0.0016 & 3.119 & 3.491 \\
\hline W10 & $550 \mathrm{~m} \mathrm{~W}$ & 3.02 & 2.98 & 0.43 & 0.05 & 0 & 42.5 & 0.01 & 0 & 0 & 5.633 & 1.563 & 0.0022 & 3.116 & 3.504 \\
\hline W11 & $750 \mathrm{~m} \mathrm{~W}$ & 167.74 & 317.83 & 0.59 & 0.4 & 25.2 & 90.8 & 0 & 0 & 0.19 & 18.886 & 9.467 & 0.0411 & 9.677 & 186.28 \\
\hline W12 & $1050 \mathrm{~m} \mathrm{~W}$ & 935.27 & 2078.69 & 3.88 & 0.36 & 0 & 120.4 & 0 & 0 & 1.65 & 36.04 & 2.457 & 0.0128 & 41.72 & 1349 \\
\hline W13 & $1197.5 \mathrm{~m} \mathrm{~W}$ & 2.32 & 2.39 & 0.42 & 0.04 & 0 & 39.7 & 0.03 & 0 & 0 & 5.346 & 1.638 & 0.0015 & 3.106 & 3.634 \\
\hline W14 & River random & 1.93 & 2.72 & 0.34 & 0.03 & 0 & 40.1 & 0 & 0 & 0 & 5.45 & 1.601 & 0.0016 & 3.187 & 3.696 \\
\hline W15 & Sewage 1 & 183.93 & 2.97 & 0.72 & 0.47 & 0 & 427 & 0 & 45.6 & 0.14 & 8.523 & 10.476 & 0.0027 & 2.791 & 134.62 \\
\hline W16 & Sewage 2 & 52.48 & 41.17 & 20.23 & 0.1 & 0 & 88.1 & 0 & 11.2 & 0.02 & 5.01 & 14.24 & 0.0061 & 6.58 & 48.46 \\
\hline & Minimum & 1.93 & 2.39 & 0 & 0.02 & 0 & 38.5 & 0 & 0 & 0 & 5.01 & 1.493 & 0.0015 & 2.791 & 3.491 \\
\hline & Maximum & 7570.65 & 6369.31 & 20.23 & 5.36 & 25.2 & 544.9 & 0.05 & 45.6 & 15.43 & 349.8 & 25.42 & 0.6286 & 41.72 & 4308 \\
\hline & Mean & 1505.72 & 1469.98 & 2.4 & 1.354 & 2.413 & 167.044 & 0.009 & 3.55 & 3.185 & 70.4709 & 8.86888 & 0.16154 & 10.8686 & 1042.12 \\
\hline
\end{tabular}

*: Direction and distance from the hot spring.

\subsubsection{Trace Elements}

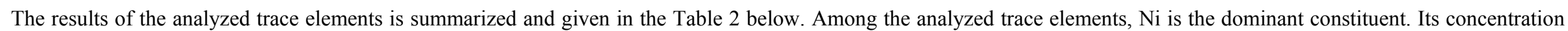

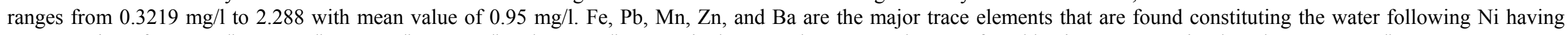
concentration of $0.12 \mathrm{mg} / 1,0.08 \mathrm{mg} / 1,0.05 \mathrm{mg} / 1,0.03 \mathrm{mg} / \mathrm{l}$ and $0.03 \mathrm{mg} / \mathrm{l}$, respectively. As, $\mathrm{Cd}, \mathrm{Co}, \mathrm{Cr}$ and $\mathrm{Cu}$ are found having concentration less than $0.001 \mathrm{mg} / \mathrm{l}$. 
Table 2. Summarized results of some of the analyzed trace elements in water samples (mg/l).

\begin{tabular}{|c|c|c|c|c|c|c|c|c|c|c|c|c|}
\hline ID & Type/Direction* & As & $\mathrm{Ba}$ & $\mathrm{Cd}$ & Co & $\mathrm{Cr}$ & $\mathrm{Cu}$ & $\mathrm{Fe}$ & $\mathrm{Mn}$ & $\mathrm{Ni}$ & $\mathrm{Pb}$ & $\mathrm{Zn}$ \\
\hline W1 & Hot spring & 0.0001 & 0.0134 & 0.0055 & 0.0014 & 0.001 & 0.0043 & 0.0014 & 0.0893 & 1.652 & 0.165 & 0.041 \\
\hline W2 & $50 \mathrm{~m} \mathrm{~N}$ & 0.0033 & 0.0354 & 0.0075 & 0.0029 & 0.0001 & 0.0041 & 0.0249 & 0.5172 & 2.228 & 0.0819 & 0.0396 \\
\hline W3 & $100 \mathrm{~m} \mathrm{~N}$ & 0.0032 & 0.053 & 0.0052 & 0.0004 & 0.0004 & 0.0034 & 0.0062 & 0.0076 & 0.8354 & 0.0865 & 0.0334 \\
\hline W4 & $150 \mathrm{~m} \mathrm{~N}$ & 0.0097 & 0.0257 & 0.0102 & 0.0013 & 0.0002 & 0.0034 & 0.0036 & 0.0491 & 2.288 & 0.0362 & 0.0493 \\
\hline W5 & $200 \mathrm{~m} \mathrm{~N}$ & 0.0067 & 0.028 & 0.0034 & 0.0004 & 0.0005 & 0.0014 & 0.0019 & 0.0713 & 1.766 & 0.0671 & 0.0423 \\
\hline W6 & $300 \mathrm{~m} \mathrm{~W}$ & 0.0061 & 0.025 & 0.0011 & 0.0018 & 0.0005 & 0.0027 & 0.0787 & 0.003 & 0.4447 & 0.1 & 0.0305 \\
\hline W7 & $350 \mathrm{~m} \mathrm{~W}$ & 0.001 & 0.0242 & 0.0024 & 0.0004 & 0.0002 & 0.0046 & 0.2102 & 0.001 & 0.424 & 0.032 & 0.0291 \\
\hline W8 & $400 \mathrm{~m} \mathrm{~W}$ & 0.001 & 0.0234 & 0.0062 & 0.0035 & 0.0002 & 0.0044 & 0.2517 & 0.0009 & 0.4666 & 0.2121 & 0.0214 \\
\hline W9 & $500 \mathrm{~m} \mathrm{~W}$ & 0.0037 & 0.0187 & 0.0033 & 0.0025 & 0.0002 & 0.004 & 0.0509 & 0.0003 & 0.4225 & 0.1114 & 0.0302 \\
\hline W10 & $550 \mathrm{~m} \mathrm{~W}$ & 0.0005 & 0.0278 & 0.0077 & 0.0013 & 0.0015 & 0.0043 & 0.6987 & 0.0017 & 0.5858 & 0.0252 & 0.0263 \\
\hline W11 & $750 \mathrm{~m} \mathrm{~W}$ & 0.004 & 0.0202 & 0.0107 & 0.0011 & 0.0004 & 0.0025 & 0.0168 & 0.0003 & 1.13 & 0.0297 & 0.0324 \\
\hline W12 & $1050 \mathrm{~m} \mathrm{~W}$ & 0.0007 & 0.0539 & 0.0038 & 0.0001 & 0 & 0.0036 & 0.0057 & 0.0002 & 0.3219 & 0.0247 & 0.0436 \\
\hline W13 & $1197.5 \mathrm{~m} \mathrm{~W}$ & 0.0014 & 0.0234 & 0.0021 & 0.0018 & 0 & 0.0046 & 0.3013 & 0.0011 & 0.4779 & 0.0143 & 0.0227 \\
\hline W14 & River random & 0.0034 & 0.0248 & 0.0032 & 0.0004 & 0.0001 & 0.0045 & 0.1525 & 0.0006 & 0.4873 & 0.0627 & 0.0029 \\
\hline W15 & Sewage 1 & 0.0036 & 0.0028 & 0.0181 & 0 & 0.0002 & 0.0024 & 0.0292 & 0.0014 & 0.7496 & 0.028 & 0.0424 \\
\hline W16 & Sewage 2 & 0.0018 & 0.028 & 0.0035 & 0.0023 & 0.0001 & 0.0031 & 0.0099 & 0.0015 & 0.8402 & 0.1546 & 0.0341 \\
\hline \multicolumn{2}{|c|}{ Minimum } & 0.0001 & 0.0028 & 0.0011 & 0 & 0 & 0.0014 & 0.0014 & 0.0002 & 0.3219 & 0.0143 & 0.0029 \\
\hline \multicolumn{2}{|c|}{ Maximum } & 0.0097 & 0.0539 & 0.0181 & 0.0035 & 0.0015 & 0.0046 & 0.6987 & 0.5172 & 2.288 & 0.2121 & 0.0493 \\
\hline \multicolumn{2}{|c|}{ Mean } & 0.00314 & 0.02673 & 0.00587 & 0.00135 & 0.00035 & 0.00358 & 0.11523 & 0.04666 & 0.94499 & 0.07696 & 0.03258 \\
\hline
\end{tabular}

*: Direction and distance from the hot spring. 


\subsubsection{Sediments}

As it was mentioned in the methodology parts, the sediments were analyzed for major cations, major anions and some trace elements. The same cations and trace elements that were analyzed for the water samples were also analyzed in the sediment samples and with exception of bicarbonate and carbonate, seven of the anions analyzed in the water samples were also analyzed in the sediments samples. The data generated for the sediment samples are given in Table 3 , 4 and 5 and are discussed below.

The results of the analysis indicate that the concentration of $\mathrm{Na}^{+}$ranges from $0.1 \mathrm{mg} / \mathrm{l}$ to $25.34 \mathrm{mg} / \mathrm{l}$ with mean value of $3.438 \mathrm{mg} / \mathrm{l}$ and $\mathrm{K}^{+}$ranges from $0.494 \mathrm{mg} / \mathrm{l}$ to $11.66 \mathrm{mg} / \mathrm{l}$ with mean value of $2.650 \mathrm{mg} / \mathrm{l}$. Ca ${ }^{2+}$ ranges from 0.1387 $\mathrm{mg} / \mathrm{l}$ to $37.7 \mathrm{mg} / \mathrm{l}$ with mean value of $3.067 \mathrm{mg} / \mathrm{l}$ while $\mathrm{Mg}^{2+}$ ranges from $0.111 \mathrm{mg} / \mathrm{l}$ to $7.21 \mathrm{mg} / \mathrm{l}$ with mean value of $1.436 \mathrm{mg} / \mathrm{l}$. Li ${ }^{+}$ranges from $0.003 \mathrm{mg} / \mathrm{l}$ to $0.046 \mathrm{mg} / \mathrm{l}$ with mean value of $0.010 \mathrm{mg} / \mathrm{l}$. Based on the mean values of the chemical parameters, the cations were in the order of abundance as $\mathrm{Na}^{+}>\mathrm{Ca}^{2+}>\mathrm{K}^{+}>\mathrm{Mg}^{2+}>\mathrm{Li}^{+}$.

The analysis of the anions indicates that there is no $\mathrm{PO}_{4}{ }^{3-}$ and $\mathrm{NO}_{2}{ }^{-}$present in the sediment samples. The concentrations of $\mathrm{F}^{-}$range from $0 \mathrm{mg} / \mathrm{l}$ to $1.463 \mathrm{mg} / \mathrm{l}$ with a mean value of $0.232 \mathrm{mg} / \mathrm{l}$. $\mathrm{Cl}^{-}$concentrations range from $0.622 \mathrm{mg} / \mathrm{l}$ to $923.5 \mathrm{mg} / \mathrm{l}$ with a mean value of $84.103 \mathrm{mg} / \mathrm{l}$. Br concentration was only present in only one sample and therefore ranged from $0 \mathrm{mg} / \mathrm{l}$ to $1.626 \mathrm{mg} / \mathrm{l}$ with a mean value of $0.068 \mathrm{mg} / \mathrm{l}$. The concentrations of $\mathrm{NO}_{3}{ }^{-}$range from $0 \mathrm{mg} / \mathrm{l}$ to $10.064 \mathrm{mg} / \mathrm{l}$ with a mean value of $1.116 \mathrm{mg} / 1 . \mathrm{SO}_{4}{ }^{2-}$ concentrations range from $0 \mathrm{mg} / \mathrm{l}$ to $1883.9 \mathrm{mg} / \mathrm{l}$ with a mean value of $347.44 \mathrm{mg} / \mathrm{l}$. Based on the mean values of the chemical parameters, the anions were in the order of abundance as $\mathrm{SO}_{4}{ }^{2-}>\mathrm{Cl}^{-}>\mathrm{NO}_{3}^{-}>\mathrm{F}^{-}>\mathrm{Br}^{-}>\mathrm{NO}_{2}^{-}>\mathrm{PO}_{4}{ }^{3-}$.

Table 3. Summarized results of the analyzed sediment samples for cations $(\mathrm{mg} / \mathrm{l})$.

\begin{tabular}{|c|c|c|c|c|c|c|}
\hline ID & Direction* & $\mathrm{Ca}^{2+}$ & $\mathrm{K}^{+}$ & $\mathrm{Li}^{+}$ & $\mathrm{Mg}^{2+}$ & $\mathrm{Na}^{+}$ \\
\hline $\mathrm{S} 1$ & $50 \mathrm{~m} \mathrm{~N}$ & 10.66 & 11.66 & 0.046 & 4.88 & 17.65 \\
\hline $\mathrm{S} 2$ & $100 \mathrm{~m} \mathrm{~N}$ & 7.51 & 6.093 & 0.0286 & 2.873 & 25.34 \\
\hline S3 & $150 \mathrm{~m} \mathrm{~N}$ & 0.5537 & 0.6386 & 0.0038 & 0.1604 & 1.357 \\
\hline $\mathrm{S} 4$ & $200 \mathrm{~m} \mathrm{~N}$ & 1.049 & 2.416 & 0.0105 & 1.007 & 0.9379 \\
\hline S5 & $50 \mathrm{~m} \mathrm{E}$ & 0.5376 & 1.228 & 0.0042 & 0.1516 & 1.009 \\
\hline S6 & $100 \mathrm{~m} \mathrm{E}$ & 0.5349 & 2.655 & 0.0088 & 0.5572 & 0.9928 \\
\hline S7 & $150 \mathrm{~m} \mathrm{E}$ & 1.176 & 3.547 & 0.022 & 1.971 & 4.054 \\
\hline $\mathrm{S} 8$ & $200 \mathrm{~m} \mathrm{E}$ & 18.23 & 8.844 & 0.0295 & 5.93 & 10.9 \\
\hline S9 & $250 \mathrm{~m} \mathrm{E}$ & 9.749 & 4.948 & 0.0161 & 3.574 & 6.363 \\
\hline S49 & $300 \mathrm{~m} \mathrm{E}$ & 2.633 & 2.705 & 0.0135 & 1.666 & 3.87 \\
\hline S10 & $350 \mathrm{~m} \mathrm{E}$ & 6.972 & 2.733 & 0.0148 & 2.177 & 2.805 \\
\hline S11 & $400 \mathrm{~m} \mathrm{E}$ & 1.845 & 3.132 & 0.0117 & 2.103 & 4.135 \\
\hline S12 & $450 \mathrm{~m} \mathrm{E}$ & 3.081 & 3.914 & 0.0146 & 3.23 & 3.317 \\
\hline $\mathrm{S} 13$ & $500 \mathrm{~m} \mathrm{E}$ & 3.653 & 3.813 & 0.0123 & 3.182 & 4.857 \\
\hline S14 & $550 \mathrm{~m} \mathrm{E}$ & 5.4 & 3.751 & 0.0162 & 4.543 & 7.813 \\
\hline S15 & $600 \mathrm{~m} \mathrm{E}$ & 37.7 & 3.674 & 0.0222 & 7.21 & 6.795 \\
\hline S16 & $50 \mathrm{~m} \mathrm{~S}$ & 1.808 & 5.008 & 0.0086 & 0.7586 & 3.305 \\
\hline S17 & $100 \mathrm{~m} \mathrm{~S}$ & 0.7566 & 1.722 & 0.0037 & 0.3735 & 2.464 \\
\hline S18 & $150 \mathrm{~m} \mathrm{~S}$ & 0.7597 & 1.695 & 0.0035 & 0.3651 & 2.424 \\
\hline S19 & $200 \mathrm{~m} \mathrm{~S}$ & 5.294 & 7.182 & 0.0179 & 3.718 & 8.678 \\
\hline S20 & $250 \mathrm{~m} \mathrm{~S}$ & 3.174 & 3.389 & 0.0049 & 1.139 & 2.627 \\
\hline S21 & $300 \mathrm{~m} \mathrm{~S}$ & 3.968 & 4.71 & 0.0112 & 2.616 & 4.556 \\
\hline S22 & $350 \mathrm{~m} \mathrm{~S}$ & 4.657 & 3.747 & 0.0111 & 2.477 & 6.7 \\
\hline S23 & $400 \mathrm{~m} \mathrm{~S}$ & 2.307 & 5.233 & 0.0121 & 3.153 & 4.783 \\
\hline S24 & $450 \mathrm{~m} \mathrm{~S}$ & 2.485 & 4.565 & 0.0081 & 2.472 & 2.146 \\
\hline S25 & $50 \mathrm{~m} \mathrm{~W}$ & 0.7858 & 2.298 & 0.0049 & 0.648 & 3.268 \\
\hline S26 & $100 \mathrm{~m} \mathrm{~W}$ & 0.1902 & 0.7339 & 0.0032 & 0.1872 & 3.27 \\
\hline S27 & $150 \mathrm{~m} \mathrm{~W}$ & 0.4219 & 1.311 & 0.004 & 0.4011 & 0.4777 \\
\hline S28 & $200 \mathrm{~m} \mathrm{~W}$ & 0.2197 & 0.6479 & 0.0027 & 0.2204 & 0.14 \\
\hline S29 & $250 \mathrm{~m} \mathrm{~W}$ & 0.1879 & 0.6725 & 0.0029 & 0.2282 & 0.26 \\
\hline S30 & $300 \mathrm{~m} \mathrm{~W}$ & 0.2723 & 0.7119 & 0.0029 & 0.1696 & 0.5794 \\
\hline S31 & $350 \mathrm{~m} \mathrm{~W}$ & 0.1387 & 0.5919 & 0.0026 & 0.1621 & 0.1 \\
\hline S32 & $400 \mathrm{~m} \mathrm{~W}$ & 0.1481 & 0.6259 & 0.0026 & 0.1734 & 0.206 \\
\hline S33 & $450 \mathrm{~m} \mathrm{~W}$ & 0.3064 & 0.9063 & 0.0041 & 0.2325 & 0.433 \\
\hline S34 & $500 \mathrm{~m} \mathrm{w}$ & 0.2523 & 1.033 & 0.0043 & 0.2479 & 0.14 \\
\hline S35 & $550 \mathrm{~m} \mathrm{w}$ & 0.8739 & 1.673 & 0.0073 & 0.7639 & 4.151 \\
\hline
\end{tabular}




\begin{tabular}{|c|c|c|c|c|c|c|}
\hline S36 & $600 \mathrm{~m} \mathrm{~W}$ & 3.83 & 1.47 & 0.0094 & 0.7384 & 3.831 \\
\hline S37 & $650 \mathrm{~m} \mathrm{~W}$ & 1.393 & 1.534 & 0.0069 & 0.5975 & 3.785 \\
\hline $\mathrm{S} 38$ & $700 \mathrm{~m} \mathrm{~W}$ & 0.3154 & 1.109 & 0.005 & 0.31 & 1.337 \\
\hline S39 & $750 \mathrm{~m} \mathrm{~W}$ & 2.286 & 1.806 & 0.0161 & 1.082 & 2.609 \\
\hline $\mathrm{S} 40$ & $800 \mathrm{~m} \mathrm{~W}$ & 0.319 & 1.361 & 0.0047 & 0.2746 & 0.7636 \\
\hline S41 & $850 \mathrm{~m} \mathrm{~W}$ & 0.2118 & 1.073 & 0.0032 & 0.1398 & 0.6649 \\
\hline $\mathrm{S} 42$ & $900 \mathrm{~m} \mathrm{~W}$ & 0.2289 & 0.9547 & 0.0039 & 0.1999 & 0.4135 \\
\hline S43 & $950 \mathrm{~m} \mathrm{~W}$ & 0.1728 & 1.065 & 0.004 & 0.2153 & 0.3268 \\
\hline S44 & $1000 \mathrm{~m} \mathrm{~W}$ & 0.2904 & 1.361 & 0.0048 & 0.274 & 0.4302 \\
\hline S45 & $1050 \mathrm{~m} \mathrm{~W}$ & 0.1867 & 1.119 & 0.0038 & 0.1767 & 0.365 \\
\hline S46 & $1100 \mathrm{~m} \mathrm{~W}$ & 0.2518 & 1.092 & 0.004 & 0.2094 & 0.3574 \\
\hline S47 & $1150 \mathrm{~m} \mathrm{~W}$ & 0.3527 & 1.166 & 0.0046 & 0.2927 & 0.4781 \\
\hline S48 & $1197.5 \mathrm{~m} \mathrm{~W}$ & 0.15 & 0.4936 & 0.003 & 0.1113 & 0.2163 \\
\hline \multicolumn{2}{|c|}{ Minimum } & 0.1387 & 0.4936 & 0.0026 & 0.1113 & 0.1 \\
\hline \multicolumn{2}{|c|}{ Maximum } & 37.7 & 11.66 & 0.046 & 7.21 & 25.34 \\
\hline \multicolumn{2}{|c|}{ Average } & 3.066922 & 2.649229 & 0.009608 & 1.435578 & 3.4384 \\
\hline
\end{tabular}

*: Direction and distance from the hot spring.

Table 4. Summarized results of the analyzed sediment samples for anions $(\mathrm{mg} / \mathrm{l})$.

\begin{tabular}{|c|c|c|c|c|c|c|c|c|}
\hline ID & Direction* & $\mathrm{PO}_{4}^{3-}$ & $\mathrm{F}^{-}$ & $\mathrm{Cl}^{-}$ & $\mathrm{NO}_{2}^{-}$ & $\mathrm{Br}^{-}$ & $\mathrm{NO}_{3}^{-}$ & $\mathrm{SO}_{4}^{2-}$ \\
\hline $\mathrm{S} 1$ & $50 \mathrm{~m} \mathrm{~W}$ & 0 & 0.61 & 109.4 & 0 & 0 & 1.485 & 84.624 \\
\hline S2 & $100 \mathrm{~m} \mathrm{~W}$ & 0 & 0 & 1.754 & 0 & 0 & 0 & 0 \\
\hline S3 & $150 \mathrm{~m} \mathrm{~W}$ & 0 & 0 & 2.477 & 0 & 0 & 0 & 1.992 \\
\hline S4 & $200 \mathrm{~m} \mathrm{~W}$ & 0 & 0 & 0.622 & 0 & 0 & 0 & 0 \\
\hline S5 & $300 \mathrm{~m} \mathrm{~W}$ & 0 & 0 & 45.6 & 0 & 0 & 0 & 35.076 \\
\hline S6 & $400 \mathrm{~m} \mathrm{~W}$ & 0 & 0 & 0.855 & 0 & 0 & 0 & 0 \\
\hline S7 & $500 \mathrm{~m} \mathrm{~W}$ & 0 & 0 & 1.165 & 0 & 0 & 0 & 0 \\
\hline $\mathrm{S} 8$ & $50 \mathrm{~m} \mathrm{~N}$ & 0 & 0 & 275.6 & 0 & 0 & 0 & 1883.9 \\
\hline S9 & $100 \mathrm{~m} \mathrm{~N}$ & 0 & 1.462 & 923.5 & 0 & 1.626 & 0 & 901.5 \\
\hline S10 & $150 \mathrm{~m} \mathrm{~N}$ & 0 & 0 & 44 & 0 & 0 & 1.888 & 42.251 \\
\hline S11 & $200 \mathrm{~m} \mathrm{~N}$ & 0 & 0 & 2.136 & 0 & 0 & 3.305 & 15.594 \\
\hline $\mathrm{S} 12$ & $50 \mathrm{~m} \mathrm{~S}$ & 0 & 0 & 26.4 & 0 & 0 & 0 & 217.8 \\
\hline S13 & $100 \mathrm{~m} \mathrm{~S}$ & 0 & 0 & 23.4 & 0 & 0 & 0 & 866.3 \\
\hline S14 & $150 \mathrm{~m} \mathrm{~S}$ & 0 & 0 & 118.5 & 0 & 0 & 0 & 144.972 \\
\hline S15 & $200 \mathrm{~m} \mathrm{~S}$ & 0 & 0.705 & 121 & 0 & 0 & 0 & 1529.4 \\
\hline S16 & $300 \mathrm{~m} \mathrm{~S}$ & 0 & 1.212 & 9.231 & 0 & 0 & 1.479 & 616.2 \\
\hline S17 & $400 \mathrm{~m} \mathrm{~S}$ & 0 & 0.447 & 35.1 & 0 & 0 & 0 & 90.46 \\
\hline S18 & $50 \mathrm{~m} \mathrm{E}$ & 0 & 0 & 74.3 & 0 & 0 & 10.064 & 60.555 \\
\hline S19 & $100 \mathrm{~m} \mathrm{E}$ & 0 & 0 & 1.724 & 0 & 0 & 0 & 0 \\
\hline S20 & $150 \mathrm{~m} \mathrm{E}$ & 0 & 0.65 & 29.7 & 0 & 0 & 3.372 & 145.402 \\
\hline S21 & $200 \mathrm{~m} \mathrm{E}$ & 0 & 0 & 20.7 & 0 & 0 & 1.619 & 692.9 \\
\hline S22 & $300 \mathrm{~m} \mathrm{E}$ & 0 & 0 & 33.4 & 0 & 0 & 0 & 428.6 \\
\hline $\mathrm{S} 23$ & $400 \mathrm{~m} \mathrm{E}$ & 0 & 0 & 75.7 & 0 & 0 & 0 & 480.7 \\
\hline S24 & $500 \mathrm{~m} \mathrm{E}$ & 0 & 0.476 & 42.2 & 0 & 0 & 3.583 & 100.234 \\
\hline \multicolumn{2}{|c|}{ Minimum } & 0 & 0 & 0.622 & 0 & 0 & 0 & 0 \\
\hline \multicolumn{2}{|c|}{ Maximum } & 0 & 1.462 & 923.5 & 0 & 1.626 & 10.064 & 1883.9 \\
\hline \multicolumn{2}{|c|}{ Average } & 0 & 0.23175 & 84.10267 & 0 & 0.06775 & 1.116458 & 347.4358 \\
\hline
\end{tabular}

\footnotetext{
*: Direction and distance from the hot spring.
}

Among the analyzed trace elements $\mathrm{Fe}, \mathrm{Ni}$ and $\mathrm{Pb}$ have dominant concentrations: the concentration of $\mathrm{Fe}$ ranges from $1.74 \mathrm{mg} / \mathrm{l}$ to $51.96 \mathrm{mg} / \mathrm{l}$ with mean value of $14.019 \mathrm{mg} / \mathrm{l}$, Ni ranges in concentration from $0.002 \mathrm{mg} / \mathrm{l}$ to $1.163 \mathrm{mg} / \mathrm{l}$ with mean value of $0.316 \mathrm{mg} / \mathrm{l}$ and the concentration of $\mathrm{Pb}$ ranges from $0.026 \mathrm{mg} / 1$ to $0.827 \mathrm{mg} / \mathrm{l}$ with mean value of 0.278 $\mathrm{mg} / \mathrm{l}$. All the remaining analyzed trace elements have a mean concentration below $0.2 \mathrm{mg} / \mathrm{l}$. Based on the mean values of the chemical parameters, the trace elements were in the order of abundance as $\mathrm{Fe}>\mathrm{Ni}>\mathrm{Pb}>\mathrm{Ba}>\mathrm{Mn}>\mathrm{Zn}>\mathrm{As}>$ $\mathrm{Cu}>\mathrm{Cr}>\mathrm{Co}>\mathrm{Cd}$. 
Table 5. Summarized results of the analyzed sediment samples for some trace elements (mg/l).

\begin{tabular}{|c|c|c|c|c|c|c|c|c|c|c|c|c|}
\hline ID & Direction* & As & $\mathrm{Ba}$ & $\mathrm{Cd}$ & Co & $\mathrm{Cr}$ & $\mathrm{Cu}$ & $\mathrm{Fe}$ & $\mathrm{Mn}$ & $\mathrm{Ni}$ & $\mathrm{Pb}$ & $\mathrm{Zn}$ \\
\hline $\mathrm{S} 1$ & $50 \mathrm{~m} \mathrm{~N}$ & 0.2211 & 0.6208 & 0.0676 & 0.0677 & 0.0807 & 0.1412 & 51.96 & 0.5508 & 0.1093 & 0.4786 & 0.2677 \\
\hline $\mathrm{S} 2$ & $100 \mathrm{~m} \mathrm{~N}$ & 0.4689 & 0.2829 & 0.0447 & 0.0298 & 0.0429 & 0.0551 & 26.51 & 0.3214 & 0.0332 & 0.3551 & 0.0413 \\
\hline $\mathrm{S} 3$ & $150 \mathrm{~m} \mathrm{~N}$ & 0.1621 & 0.0446 & 0.0109 & 0.0082 & 0.0134 & 0.0046 & 2.409 & 0.0767 & 0.5632 & 0.2887 & 0.0049 \\
\hline S4 & $200 \mathrm{~m} \mathrm{~N}$ & 0.0035 & 0.1363 & 0.0067 & 0.0143 & 0.03 & 0.0107 & 9.894 & 0.0782 & 0.138 & 0.4315 & 0.1133 \\
\hline S5 & $50 \mathrm{~m} \mathrm{E}$ & 0.006 & 0.0968 & 0.0005 & 0.0086 & 0.0109 & 0.0045 & 1.74 & 0.0345 & 0.0591 & 0.2141 & 0.0444 \\
\hline S6 & $100 \mathrm{~m} \mathrm{E}$ & 0.0059 & 0.1451 & 0.0021 & 0.0141 & 0.0146 & 0.0116 & 6.865 & 0.0839 & 0.2935 & 0.6802 & 0.1997 \\
\hline $\mathrm{S} 7$ & $150 \mathrm{~m} \mathrm{E}$ & 0.1541 & 0.2015 & 0.0173 & 0.0245 & 0.0302 & 0.0259 & 16.86 & 0.1665 & 0.2609 & 0.674 & 0.0984 \\
\hline $\mathrm{S} 8$ & $200 \mathrm{~m} \mathrm{E}$ & 0.0505 & 0.4149 & 0.0143 & 0.0327 & 0.0451 & 0.0681 & 33.13 & 0.3105 & 0.0347 & 0.4694 & 0.1564 \\
\hline S9 & $250 \mathrm{~m} \mathrm{E}$ & 0.1703 & 0.3226 & 0.0199 & 0.0318 & 0.0455 & 0.0684 & 29.22 & 0.2797 & 0.2316 & 0.4339 & 0.0012 \\
\hline S49 & $300 \mathrm{~m} \mathrm{E}$ & 0.136 & 0.3907 & 0.0147 & 0.0185 & 0.0459 & 0.0388 & 19.43 & 0.2441 & 0.1039 & 0.1874 & 0.0707 \\
\hline S10 & $350 \mathrm{~m} \mathrm{E}$ & 0.0361 & 0.1854 & 0.0082 & 0.0196 & 0.0336 & 0.0406 & 20.52 & 0.3183 & 0.0641 & 0.1845 & 0.0026 \\
\hline S11 & $400 \mathrm{~m} \mathrm{E}$ & 0.0968 & 0.1758 & 0.0126 & 0.0228 & 0.0298 & 0.0438 & 23.61 & 0.3037 & 0.0488 & 0.1921 & 0.0167 \\
\hline S12 & $450 \mathrm{~m} \mathrm{E}$ & 0.0086 & 0.1991 & 0.0126 & 0.0278 & 0.0403 & 0.0621 & 34.01 & 0.2918 & 0.3464 & 0.3063 & 0.0173 \\
\hline S13 & $500 \mathrm{~m} \mathrm{E}$ & 0.1397 & 0.2768 & 0.0195 & 0.0376 & 0.0373 & 0.0648 & 31.93 & 0.4598 & 1.1114 & 0.2776 & 0.0224 \\
\hline S14 & $550 \mathrm{~m} \mathrm{E}$ & 0.4498 & 0.2799 & 0.0468 & 0.0395 & $0.04-38$ & 0.081 & 39.46 & 0.4397 & 0.244 & 0.0573 & 0.0078 \\
\hline S15 & $600 \mathrm{~m} \mathrm{E}$ & 0.0846 & 0.3583 & 0.0179 & 0.0394 & 0.0487 & 0.0898 & 41.23 & 0.9353 & 0.9265 & 0.4186 & 0.0855 \\
\hline S16 & $50 \mathrm{~m} \mathrm{~S}$ & 0.0267 & 0.2902 & 0.0029 & 0.018 & 0.0176 & 0.0216 & 9.574 & 0.1134 & 0.2894 & 0.4791 & 0.0743 \\
\hline S17 & $100 \mathrm{~m} \mathrm{~S}$ & 0.2261 & 0.4997 & 0.0163 & 0.006 & 0.0071 & 0.0103 & 5.253 & 0.0671 & 0.6755 & 0.1313 & 0.1522 \\
\hline S18 & $150 \mathrm{~m} \mathrm{~S}$ & 0.2161 & 0.4942 & 0.0174 & 0.0032 & 0.0077 & 0.0107 & 5.16 & 0.0661 & 0.0416 & 0.1345 & 0.1437 \\
\hline S19 & $200 \mathrm{~m} \mathrm{~S}$ & 0.4943 & 0.4229 & 0.0485 & 0.047 & 0.0655 & 0.1102 & 44.04 & 0.3339 & 0.3558 & 0.8272 & 0.1594 \\
\hline S20 & $250 \mathrm{~m} \mathrm{~S}$ & 0.2025 & 0.2333 & 0.0192 & 0.0168 & 0.0158 & 0.0221 & 14.76 & 0.1621 & 0.0604 & 0.2306 & 0.1006 \\
\hline S21 & $300 \mathrm{~m} \mathrm{~S}$ & 0.0415 & 0.3166 & 0.0093 & 0.0286 & 0.0372 & 0.0568 & 25.83 & 0.2712 & 0.2357 & 0.1667 & 0.1624 \\
\hline S22 & $350 \mathrm{~m} \mathrm{~S}$ & 0.3621 & 0.8927 & 0.0345 & 0.0178 & 0.0296 & 0.0447 & 23.95 & 0.3761 & 0.075 & 0.1581 & 0.0074 \\
\hline S23 & $400 \mathrm{~m} \mathrm{~S}$ & 0.2813 & 0.1855 & 0.0304 & 0.0345 & 0.0437 & 0.0634 & 31.74 & 0.2668 & 0.1682 & 0.4187 & 0.0484 \\
\hline S24 & $450 \mathrm{~m} \mathrm{~S}$ & 0.0053 & 0.2314 & 0.0107 & 0.029 & 0.0333 & 0.084 & 23.78 & 0.4423 & 0.2289 & 0.5904 & 0.0592 \\
\hline S25 & $50 \mathrm{~m} \mathrm{~W}$ & 0.6229 & 0.1656 & 0.05 & 0.014 & 0.0148 & 0.0158 & 11.7 & 0.0808 & 0.0017 & 0.0911 & 0.2402 \\
\hline S26 & $100 \mathrm{~m} \mathrm{~W}$ & 0.0006 & 0.0572 & 0.0009 & 0.0095 & 0.0069 & 0.0035 & 2.665 & 0.0333 & 0.1474 & 0.0743 & 0.1965 \\
\hline S27 & $150 \mathrm{~m} \mathrm{~W}$ & 0.003 & 0.1048 & 0.0045 & 0.009 & 0.0121 & 0.008 & 5.302 & 0.0716 & 0.1872 & 0.2197 & 0.1242 \\
\hline S28 & $200 \mathrm{~m} \mathrm{~W}$ & 0.0008 & 0.0606 & 0.0037 & 0.0098 & 0.0099 & 0.0053 & 2.892 & 0.0491 & 0.3846 & 0.0372 & 0.154 \\
\hline
\end{tabular}




\begin{tabular}{|c|c|c|c|c|c|c|c|c|c|c|c|c|}
\hline S29 & $250 \mathrm{~m} \mathrm{~W}$ & 0.0018 & 0.0557 & 0.0001 & 0.0109 & 0.0092 & 0.0042 & 2.942 & 0.04 & 0.7639 & 0.0456 & 0.1165 \\
\hline S30 & $300 \mathrm{~m} \mathrm{~W}$ & 0.0181 & 0.0662 & 0.0008 & 0.0062 & 0.0083 & 0.0049 & 2.233 & 0.0295 & 0.6136 & 0.1769 & 0.1831 \\
\hline S31 & $350 \mathrm{~m} \mathrm{~W}$ & 0.0026 & 0.0514 & 0.001 & 0.0124 & 0.0089 & 0.0143 & 1.993 & 0.0259 & 0.3868 & 0.0677 & 0.0586 \\
\hline S32 & $400 \mathrm{~m} \mathrm{~W}$ & 0.0021 & 0.0523 & 0.0013 & 0.011 & 0.0067 & 0.0026 & 2.11 & 0.0279 & 0.3336 & 0.2274 & 0.0931 \\
\hline S33 & $450 \mathrm{~m} \mathrm{~W}$ & 0.0012 & 0.0597 & 0.0017 & 0.0096 & 0.0095 & 0.0038 & 3.522 & 0.0382 & 0.7363 & 0.2669 & 0.1124 \\
\hline S34 & $500 \mathrm{~m} \mathrm{w}$ & 0.0025 & 0.0686 & 0.0011 & 0.0098 & 0.0104 & 0.0042 & 3.466 & 0.0361 & 0.2142 & 0.4765 & 0.1945 \\
\hline S35 & $550 \mathrm{~m} \mathrm{w}$ & 0.1597 & 0.1306 & 0.0147 & 0.0167 & 0.0257 & 0.0132 & 10.07 & 0.0894 & 1.163 & 0.1521 & 0.1297 \\
\hline S36 & $600 \mathrm{~m} \mathrm{~W}$ & 0.3411 & 0.1205 & 0.0275 & 0.014 & 0.0229 & 0.0105 & 8.804 & 0.0575 & 0.1917 & 0.0262 & 0.17 \\
\hline S37 & $650 \mathrm{~m} \mathrm{~W}$ & 0.0984 & 0.1205 & 0.0096 & 0.0156 & 0.0234 & 0.0087 & 8.34 & 0.0853 & 0.3323 & 0.106 & 0.1237 \\
\hline S38 & $700 \mathrm{~m} \mathrm{~W}$ & 0.0062 & 0.0824 & 0.0007 & 0.0119 & 0.0117 & 0.0053 & 4.528 & 0.0459 & 0.0516 & 0.053 & 0.167 \\
\hline S39 & $750 \mathrm{~m} \mathrm{~W}$ & 0.1565 & 0.1044 & 0.013 & 0.0114 & 0.0296 & 0.011 & 11 & 0.1065 & 0.6607 & 0.3516 & 0.1405 \\
\hline $\mathrm{S} 40$ & $800 \mathrm{~m} \mathrm{~W}$ & 0.0067 & 0.0931 & 0.0021 & 0.0101 & 0.0116 & 0.004 & 3.845 & 0.0406 & 0.2243 & 0.4118 & 0.1417 \\
\hline S41 & $850 \mathrm{~m} \mathrm{~W}$ & 0.0022 & 0.0907 & 0.0004 & 0.0113 & 0.0094 & 0.037 & 2.338 & 0.0395 & 0.3732 & 0.1517 & 0.1611 \\
\hline S42 & $900 \mathrm{~m} \mathrm{~W}$ & 0.0024 & 0.0643 & 0.0003 & 0.0094 & 0.0131 & 0.0039 & 3.24 & 0.037 & 0.2025 & 0.3768 & 0.1048 \\
\hline $\mathrm{S} 43$ & $950 \mathrm{~m} \mathrm{~W}$ & 0.0009 & 0.0665 & 0.0005 & 0.01 & 0.0118 & 0.0056 & 3.933 & 0.0314 & 0.4199 & 0.4715 & 0.133 \\
\hline S44 & $1000 \mathrm{~m} \mathrm{~W}$ & 0.0052 & 0.0878 & 0.0002 & 0.0117 & 0.0134 & 0.0061 & 5.538 & 0.0424 & 0.5035 & 0.121 & 0.1818 \\
\hline S45 & $1050 \mathrm{~m} \mathrm{~W}$ & 0.0038 & 0.0716 & 0.0006 & 0.0102 & 0.0104 & 0.006 & 3.319 & 0.0368 & 0.196 & 0.516 & 0.1392 \\
\hline S46 & $1100 \mathrm{~m} \mathrm{~W}$ & 0.0013 & 0.0683 & 0.0029 & 0.0093 & 0.0106 & 0.0044 & 3.499 & 0.0359 & 0.0769 & 0.073 & 0.1539 \\
\hline S47 & $1150 \mathrm{~m} \mathrm{~W}$ & 0 & 0.0766 & 0.0003 & 0.0095 & 0.0127 & 0.0057 & 4.887 & 0.0383 & 0.441 & 0.1619 & 0.1748 \\
\hline $\mathrm{S} 48$ & $1197.5 \mathrm{~m} \mathrm{~W}$ & 0 & 0.0425 & 0.0009 & 0.0078 & 0.0054 & 0.005 & 1.896 & 0.0255 & 0.192 & 0.1995 & 0.1559 \\
\hline Minimum & \multicolumn{2}{|c|}{0} & 0.0425 & 0.0001 & 0.0032 & 0.0054 & 0.0026 & 1.74 & 0.0255 & 0.0017 & 0.0262 & 0.0012 \\
\hline Maximum & \multicolumn{2}{|c|}{0.6229} & 0.8927 & 0.0676 & 0.0677 & 0.0807 & 0.1412 & 51.96 & 0.9353 & 1.163 & 0.8272 & 0.2677 \\
\hline Mean & \multicolumn{2}{|c|}{0.112039} & 0.19714 & 0.01315 & 0.01835 & 0.02365 & 0.02914 & 14.0189 & 0.16609 & 0.31627 & 0.27839 & 0.1145 \\
\hline
\end{tabular}

*: Direction and distance from the hot spring. 


\subsubsection{Petrographic Analysis}

The geology of the study area comprises of the basaltic rocks of the Karoo lavas. However, outcrops of these rocks are rare in the area; they are covered by deposits of the Kalahari beds.

Five representative rock samples were collected from the patchy outcropped of the basaltic rocks in the vicinity of the hot spring for petrographic analysis.

In the hand specimen the basalt appears greenish grey with white and green amygdules. The white amygdules are more prevalent than the green amygdules.

In thin section the analyzed samples of the basalt show amygdaloidal texture with variable sizes of amygdules The size of the amygdules varies up to $2 \mathrm{~mm}$. The predominant white amygdules in the hand specimen turned out to be filled by zeolites with generally course grain size. In local places the vesicles are visible in the basalt and display variable sizes. This indicates that the basalt initially had a vesicular texture which resulted from high gas content released during the crystallization of the basalt.

The petrographic investigation shows that the basalt is essentially made up of fine lath-shaped plagioclase and fine anhedral clinopyroxene crystals associated with considerable amount of opaque minerals. The grain size of the plagioclase and pyroxenes are mostly less than $0.5 \mathrm{~mm}$. The volume percentage of the plagioclase in the basalt is quite variable ranging between $70 \%$ and $45 \%$. Moreover, the grain sizes of the plagioclase crystals are locally variable. In some samples the amount of clinopyroxene exceeds that of plagioclase. This indicates that the basalt has variable modal composition.

The modal content of the opaque minerals vary between 5 and $10 \%$. Othopyroxene and amphibole occur in trace amounts.

\subsection{Discussion}

\subsubsection{Physico-chemical Parameters}

The spring and the groundwater from the pits north of the spring are slightly alkaline to alkaline, brackish to saline and hard to very hard whereas the groundwater west of the springs, river water and the sewage water are acidic to slightly alkaline (with the exception of sample W11, which is alkaline), fresh (with the exception of sample W12, which is brackish) and soft to hard.

The TDS value of the spring water and all the samples of groundwater from the pits north of the hot spring show a significant high value of TDS as compared to the groundwater samples from the west of the spring, the sewage and the river waters. This suggests that the hot spring is not from infiltration of local precipitation or fresh surface water. The source area is of regional rather than local extent

With the exception of one groundwater samples (W5, $200 \mathrm{~m} \mathrm{~N}$ of the spring), all the samples of the groundwater from the pits north of the hot spring and the hot spring show a hardness greater than the alkalinity, signifying non-carbonate hardness. The water samples from sewage, river and all the groundwater samples from the pits west of the hot spring (with the exception of one groundwater samples from the west, W12), however, show a hardness less than the alkalinity; suggesting the hardness of these waters is carbonate hardness.

The non-carbonate hardness nature of the hot spring and all the groundwater north of the hot spring also revealed that the origin of the hot spring and the groundwater north of the hot spring is not local rather a result of deep water circulation from buried regional structures.

More or less similarities in the TDS and $\mathrm{pH}$ values and identical carbonate hardness nature between the river samples and the groundwater samples from the pits west of the hot spring suggest that the groundwater in the west of the hot spring have a source similar to the river, which is direct precipitations and/or fresh surface water from rainfall; and the groundwater is the percolation of either or both of these sources.

\subsubsection{Rock-Water Interaction}

During weathering and water circulation in rocks and soils, ions are leached out and dissolved in groundwater. The geological formations, water-rock interaction and relative mobility of ions are prime factors influencing the geochemistry of groundwater. The use of scattered plots for TDS vs $\mathrm{Na} /(\mathrm{Na}+\mathrm{Ca})$ and TDS vs $\mathrm{Cl} /\left(\mathrm{Cl}+\mathrm{HCO}_{3}\right)$ can help to identify rock-water interaction processes.

As shown in the figure 4, the hot spring, all the samples of the groundwater from the pits north of the hot spring and two samples (W11 and W12) of the groundwater from the pits west of hot spring lie in the region of evaporation crystallization dominance whereas all the samples of the groundwater from the pits west of the hot springs (with the exception of sample W11 and W12) and the river water lies on the boundary of rock weathering dominance and atmospheric precipitation dominance signifying the role that both of them play in the chemistry of the groundwater west of the hot spring and the river water.

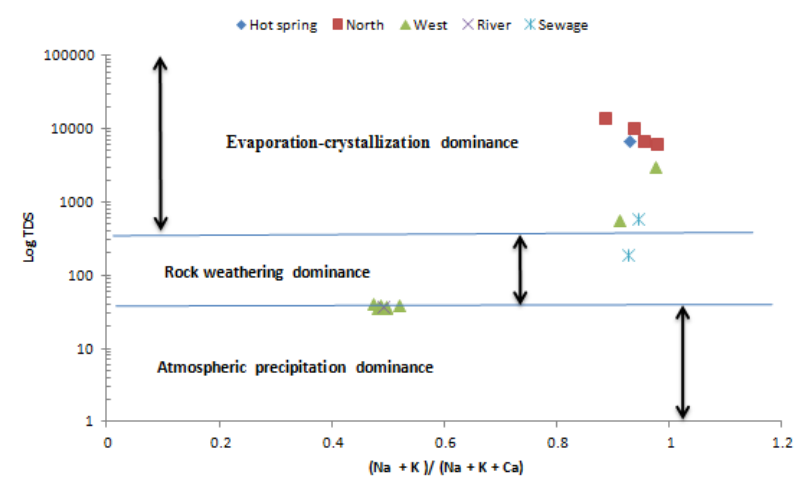




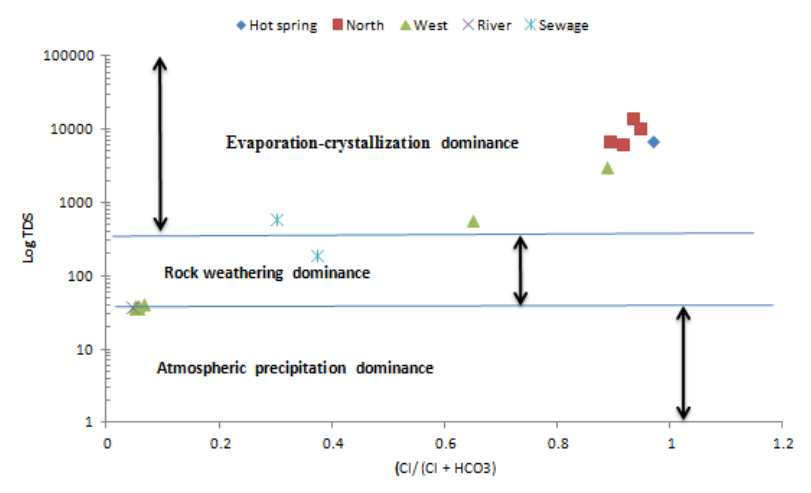

Figure 4 Gibbs diagram for cations and anions in (meq/l).

The impact of the rock weathering dominance to the chemistry of groundwater is dependent on the type of rock weathering processes that operate while the groundwater percolates through the different geological formations of the area: precipitation induced chemical weathering along with the dissolution of rock-forming minerals can modify the groundwater chemistry.

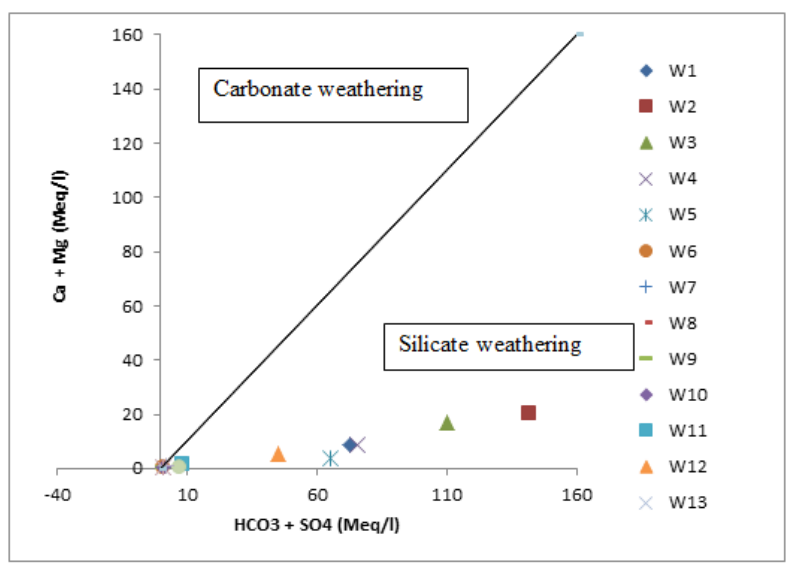

Figure $5(\mathrm{Ca}+\mathrm{Mg})$ versus $\left(\mathrm{HCO}_{3}+\mathrm{SO}_{4}\right)$ scatter diagram for the study area.

To differentiate the rock weathering processes that operate in the area under study the samples were plotted in the figure $5, \mathrm{Ca}+\mathrm{Mg} \mathrm{Vs} \mathrm{HCO}_{3}+\mathrm{SO}_{4}$. As shown in the figure the hot spring, all the samples of the groundwater from the pits north of the hot spring and two groundwater samples from the pits west of the hot spring (W11 and W12) lie below equiline $1: 1$, indicating silicate weathering is the major weathering process that has influenced the chemistry of the groundwater

All the samples of the groundwater from the pits west of the hot spring, with the exception of W11 and W12, and the river water samples, however, fall along the equiline 1:1, indicating that samples have a balanced concentrations of $\mathrm{Ca}+\mathrm{Mg})$ and $\left(\mathrm{HCO}_{3}+\mathrm{SO}_{4}\right)$.

\subsubsection{Cations, Anions and Trace Elements}

From the analysis of the major ions in the water samples, it was observed that $\mathrm{Ca}^{2+}$ and $\mathrm{Na}^{+}$are the dominant cations, with the exception of sample W12, which is from west of the hot spring, where the concentration $\mathrm{Mg}^{2+}$ is greater than that of the concentration of $\mathrm{Ca}^{2+}$. In the hot spring and in all the analyzed samples north of the hot spring $\mathrm{Na}^{+}$is the dominant cation followed by $\mathrm{Ca}^{2+}$ and $\mathrm{Mg}^{2+}$ whereas in all the samples west of the hot spring $\mathrm{Ca}^{2+}$ is the dominant cation followed by $\mathrm{Na}^{+}$and $\mathrm{Mg}^{2+}$. In sample W12 $\mathrm{Na}^{+}$is followed by $\mathrm{Mg}^{2+}$ and $\mathrm{Ca}^{2+}$. The concentrations of both $\mathrm{K}^{+}$ and $\mathrm{Li}^{+}$in the hot spring and all the groundwater samples from the pits north of the hot spring are greater than the concentrations in all the other samples.

$\mathrm{A} \mathrm{Ca}^{2+} / \mathrm{Mg}^{2+}$ molar ratio in water samples that is equal to one indicates dissolution of dolomite rocks, while a greater ratio may represent a more dominant calcite contribution from the rocks. $\mathrm{A} \mathrm{Ca}^{2+} / \mathrm{Mg}^{2+}$ ratio, greater than 2 represents the dissolution of silicate minerals into the groundwater [8]. The hot spring sample and all the groundwater samples from the pits north of the hot spring have a Ca ${ }^{2+} / \mathrm{Mg}^{2+}$ ratio greater than 2, which indicated the dissolution of silicate minerals into the groundwater. The abundance of $\mathrm{Ca}^{2+}$ and $\mathrm{Mg}^{2+}$ in the hot spring and all the groundwater samples from the pits north of the hot spring could be related to the presence of basaltic rocks in the area in which silicate minerals are the dominant minerals in the rocks. Weathering of these minerals might have contributed $\mathrm{Ca}^{2+}$ and $\mathrm{Mg}^{2+}$ to the spring and groundwater (Eq 2 to 4). The thin section study of the rocks from the studied area indicated that plagioclase and pyroxenes are the two dominant minerals in the rock. The weathering of plagioclase, pyroxene and biotite minerals could be represented in the following reactions; equations (2) to (4) in natural systems:

$$
\begin{aligned}
& \mathrm{CaAlSi}_{2} \mathrm{O}_{8} \text { (plagioclase [anorthite]) }+2 \mathrm{CO}_{2}+3 \mathrm{H}_{2} \mathrm{O} \rightarrow \\
& \text { Clay minerals (e.g kaolinite) }+\mathrm{Ca}^{2+}+2 \mathrm{HCO}_{3} \\
& \left.2 \mathrm{CaMgFeAl}_{2} \mathrm{Si}_{3} \mathrm{O}_{12} \text { (pyroxene) }+8 \mathrm{CO}_{2}+0.5\right)_{2}+11 \mathrm{H}_{2} \mathrm{O} \\
& \rightarrow 2 \text { Clay minerals (e.g kaolinite) }+2 \mathrm{Fe}(\mathrm{OH})_{3}+2 \mathrm{Ca}^{2+} \\
& +2 \mathrm{Mg}^{2+}+8 \mathrm{HCO}_{3}^{-}+2 \mathrm{SiO}_{2} \\
& 2 \mathrm{~K}\left(\mathrm{Mg}_{2} \mathrm{Fe} 2+\right) \mathrm{AlSiO}_{10}(\mathrm{OH})_{2} \text { (biotite)+ } \\
& +10 \mathrm{CO}_{2}+0.5 \mathrm{O}_{2}+8 \mathrm{H}_{2} \mathrm{O} \rightarrow \\
& \rightarrow \text { 2clay minerals (e.g kaolinite) }+2 \mathrm{Fe}(\mathrm{OH})_{3}+ \\
& +2 \mathrm{~K}^{+}+4 \mathrm{Mg}^{2+}+10 \mathrm{HCO}_{3}{ }^{-}+4 \mathrm{SiO}_{2}
\end{aligned}
$$

With the exception of two samples, all the groundwater samples from the pits west of the hot spring had a $\mathrm{Ca}^{2+} / \mathrm{Mg}^{2+}$ ratio between 1 and 2, which indicated that the dissolution of calcite. One of the groundwater samples from the pits west of the hot spring had a $\mathrm{Ca}^{2+} / \mathrm{Mg}^{2+}$ ratio higher than 2 indicating the dissolution of silicate minerals. This sample is the one nearest to the hot spring as compared to the others. The other groundwater sample from the pits west of the hot spring had a $\mathrm{Ca}^{2+} / \mathrm{Mg}^{2+}$ ratio 
less than one. The river sample reflects the same value to that of the groundwater samples from the pits west of the hot spring

With the exception of one sample, $\mathrm{Ca}^{2+} / \mathrm{Mg}^{2+}$ ratio values of groundwater samples from the pits west of the hot spring are slightly higher than river water; suggesting that the groundwater is recent and does not have long residence time within the rocks of the area. This slight increment of $\mathrm{Ca}^{2+} / \mathrm{Mg}^{2+}$ ratio values in the groundwater is due to more dominant calcium contribution from the dissolution of plagioclase minerals in the rocks of the study area as it was explained above in the form of reaction $(\mathrm{Eq} 2)$.

The trend of concentrations of $\mathrm{Na}^{+}$and $\mathrm{K}^{+}$ions in all the analyzed samples are different from that of $\mathrm{Ca}^{2+}$ and $\mathrm{Mg}^{2+}$. In the hot springs and in all the samples of the groundwater from the pits north of the hot spring the concentrations of $\mathrm{Na}^{+}$and $\mathrm{K}^{+}$ions are much higher than the concentration of $\mathrm{Ca}^{2+}$ and $\mathrm{Mg}^{2+}$ ions: suggesting that the dissolution of plagioclase and pyroxene minerals is not the only source of these elevated values of $\mathrm{Na}^{+}$and $\mathrm{K}^{+}$ions in these water. In all the samples of groundwater from the pits west of the hot spring and river water, the concentrations of $\mathrm{Na}^{+}$and $\mathrm{K}^{+}$ions show the same trend to that of the concentrations of $\mathrm{Ca}^{2+}$ and $\mathrm{Mg}^{2+}$ in these water. The elevated concentrations of $\mathrm{Na}^{+}$and $\mathrm{K}^{+}$ions in the hot springs and in all the samples of the groundwater from the pits north of the hot spring signifying more supplements of the deep fluids that have deep origin.

The general dominance of anions in the hot spring and all the groundwater samples from the pits north of the hot spring were in the order of $\mathrm{Cl}^{-}>\mathrm{SO}_{4}{ }^{2-}>\mathrm{HCO}_{3}{ }^{-}>\mathrm{Br}^{-}>\mathrm{F}^{-}>$ $\mathrm{CO}_{3}{ }^{2-}>\mathrm{NO}_{3}^{-}$. In all the samples west of the hot springs and the river water the dominant anion is bicarbonates with chloride being subdominant, followed by sulphate : $\mathrm{HCO}_{3}{ }^{-}>$ $\mathrm{Cl}^{-}>\mathrm{SO}_{4}{ }^{2-}>\mathrm{PO}_{4}{ }^{3-}>\mathrm{NO}_{3}{ }^{-}>\mathrm{F}^{--}>\mathrm{Br}^{-}>\mathrm{NO}_{2}^{-}$. This is with an exception to two samples (sample W11 and W12). In the two samples sulphate is the dominant anion with chloride being subdominant, followed by bicarbonate: $\mathrm{SO}_{4}{ }^{2-}>\mathrm{Cl}^{-}>\mathrm{HCO}_{3}{ }^{-}>\mathrm{CO}_{3}{ }^{2--}>\mathrm{NO}_{3}>\mathrm{Br}^{-}>\mathrm{F}^{-}$.

$\mathrm{Cl}^{-}$and $\mathrm{SO}_{4}{ }^{2-}$ are not the major constituents in the minerals of basaltic rocks. The dominancy of $\mathrm{Cl}^{-}$and $\mathrm{SO}_{4}{ }^{2-}$ in the hot spring and in all the samples of the groundwater from the pits north of the hot spring suggesting more supplements of the deep fluids that have deep origin.

With exception of sewage water, $\mathrm{PO}_{4}{ }^{3-}$ is absent in all the analysed water samples. In sewage water its concentration reaches up to $88.1 \mathrm{mg} / 1 . \mathrm{NO}_{2}{ }^{-}$are absent in the hot spring, in all the groundwater samples from the pits north of the hot springs, in the river water sample and in sewage samples. In the samples of the groundwater from the pits west of the hot spring $\mathrm{NO}_{2}^{-}$exist only in the samples W6, W7, W9, W10 and W13 only having minor concentration. In the remaining samples is $\mathrm{NO}_{2}^{-}$absent. With the exception of one of the sewage sample $\left(\mathrm{NO}_{3}{ }^{-}=\right.$ $20.23 \mathrm{mg} / \mathrm{l}), \mathrm{NO}_{3}{ }^{-}$is found having a minor concentration in all the analyzed water samples. The high concentrations of $\mathrm{PO}_{4}{ }^{3-}$ and $\mathrm{NO}_{3}{ }^{-}-$in the sewage water are mainly attributed to sewage effluents. Nitrogen compounds (ammonium salts, nitrites and nitrates, etc.) found in urban water bodies are mainly due to decomposition of proteinous compounds which enter with sewage. In the hot spring and in all the samples of groundwater from the pits north of the hot spring bromide was detected having a significant concentration whereas in all the samples of groundwater from the pits west of the hot spring, river samples and sewage samples the concentrations of bromide is minor. The existence of bromide having such concentrations in the hot spring and in all the samples of the groundwater from pits north of the hot spring is attributed to the supplements of the deep fluids that have deep origin.

The analyzed cations and anions in both sediments and water samples more or less show the same trend of dominancy but vary in magnitude of concentration. In the sediments samples the dominant cations are $\mathrm{Na}^{+}, \mathrm{Ca}^{2+}$ and $\mathrm{K}^{+}$and the dominant anions are $\mathrm{Cl}^{-}$and $\mathrm{SO}_{4}{ }^{2-}$. Such compositional nature of the sediments suggests that the source of the cations and anions for the water is not linked to the composition of the sediments rather to the different processes and origin describe above.

The analyzed trace elements in both the sediments and water samples more or less exhibit the same trend of dominancy but vary in magnitude of concentrations. The concentration of each analyzed trace element is greater in sediment than in the water with the exception of the concentration of $\mathrm{Ni}$ : the concentration of $\mathrm{Ni}$ in the water samples is greater than the concentration of $\mathrm{Ni}$ in the sediments.

The concentration of $\mathrm{Ni}$ is high in the hot spring and the groundwater from the pits north of the hot spring followed by the sewage water and then the groundwater samples from the pits west of the hot spring and the river samples.

The abundance of $\mathrm{Ni}$ in igneous rocks generally correlates with those of $\mathrm{Mg}, \mathrm{Cr}$ and $\mathrm{Co}$. Even though the bed rocks are basaltic rocks, this general truth is not applicable in the case of the study area. Ni concentration is much higher than the concentration of $\mathrm{Cr}$ and $\mathrm{Co}$. The mean concentration of $\mathrm{Ni}$ in the hot spring and the groundwater samples from the pits north of the hot spring is $1.754 \mathrm{mg} / \mathrm{l}$. The mean concentration of $\mathrm{Ni}$ for the groundwater samples from the pits west of the hot springs and river water sample is $0.529 \mathrm{mg} / 1$ whereas from the sewage samples the mean is $0.795 \mathrm{mg} / \mathrm{l}$. The high concentration of $\mathrm{Ni}$ in the groundwater west of the hot springs, river water and sewage is both by silicate weathering, sewage itself and leachate from the waste. The high concentration of $\mathrm{Ni}$ in the hot spring and in the groundwater from the hot spring is related deep seated origin of the fluid or magmatic fluids.

All the remaining analyzed trace elements in the groundwater from pits west of the hot springs, sewage and 
river could be derived from precipitation dissolution of minerals. Generally, the analysed trace elements in the hot spring and in the groundwater samples from the pits north of the hot spring have origin from fluids of deep origin.

All the analyzed trace elements, in the sediments from samples west, east, south of the hot spring are could be derived from silicate weathering. The iron $(\mathrm{Fe})$ concentration in the sediment is much higher than its concentration in the water samples. Since clay minerals carry more iron than sand grains, this element is principally associated with silt-clay fraction.

\subsubsection{Water Suitability}

The analyzed cations, anions and trace elements of the hot spring water and all the samples of groundwater from the pits north and west of the hot spring are compared and evaluated with respect to the drinking water standards set by Botswana Bureau of Standards (BOBS) [9] and World Health Organisation (WHO) [10] (table 6).

Table 6. Drinking water standards by $\mathrm{WHO}$ and BOBS.

\begin{tabular}{|c|c|c|}
\hline & BOBS & WHO \\
\hline $\mathrm{EC}(\mu \mathrm{S} / \mathrm{cm})$ & $1500-3100$ & 1500 \\
\hline $\mathrm{pH}$ & $5-10$ & $6.5-9.5$ \\
\hline TDS (mg/l) & $1000-2000$ & \\
\hline $\mathrm{Ca}(\mathrm{mg} / \mathrm{l})$ & $150-200$ & \\
\hline $\mathrm{K}(\mathrm{mg} / \mathrm{l})$ & $50-100$ & \\
\hline $\mathrm{Na}(\mathrm{mg} / \mathrm{l})$ & $200-400$ & 200 \\
\hline $\mathrm{Mg}(\mathrm{mg} / \mathrm{l})$ & $70-100$ & \\
\hline $\mathrm{Cl}(\mathrm{mg} / \mathrm{l})$ & $200-600$ & 250 \\
\hline $\mathrm{F}(\mathrm{mg} / \mathrm{l})$ & $1-1.5$ & 1.5 \\
\hline $\mathrm{NO}_{3}(\mathrm{mg} / \mathrm{l})$ & 50 & 50 \\
\hline $\mathrm{NO}_{2}(\mathrm{mg} / \mathrm{l})$ & 3 & 3 \\
\hline $\mathrm{SO}_{4}{ }^{2-}(\mathrm{mg} / \mathrm{l})$ & $250-400$ & 500 \\
\hline $\mathrm{Zn}(\mathrm{mg} / \mathrm{l})$ & $5-10$ & \\
\hline As (mg/l) & 0.01 & 0.01 \\
\hline $\mathrm{Cd}(\mathrm{mg} / \mathrm{l})$ & 0.003 & 0.003 \\
\hline $\mathrm{Cr}(\mathrm{mg} / \mathrm{l})$ & 0.05 & 0.05 \\
\hline $\mathrm{Co}(\mathrm{mg} / \mathrm{l})$ & $0.5-1$ & \\
\hline $\mathrm{Cu}(\mathrm{mg} / \mathrm{l})$ & 2 & 2 \\
\hline $\mathrm{Fe}(\mathrm{mg} / \mathrm{l})$ & $0.3-2$ & \\
\hline $\mathrm{Pb}(\mathrm{mg} / \mathrm{l})$ & 0.01 & 0.01 \\
\hline $\mathrm{Mn}(\mathrm{mg} / \mathrm{l})$ & $0.1-0.5$ & 0.4 \\
\hline $\mathrm{Ni}(\mathrm{mg} / \mathrm{l})$ & 0.07 & 0.02 \\
\hline $\mathrm{Ba}(\mathrm{mg} / \mathrm{l})$ & 0.7 & 0.7 \\
\hline
\end{tabular}

The hot spring, all the samples of groundwater from the pits north and west of the hot spring satisfy the $\mathrm{pH}$ drinking water standard of both WHO and Botswana Bureau of Standards.

With the exception of the sample W12, all the samples of groundwater from pits west of the hot spring suit the EC and TDS standard of both WHO and Botswana Bureau of Standards whereas sample W12, hot spring water and all the samples of groundwater from the pits north of the hot spring is highly above the recommended limits of standards set by both WHO and Botswana Bureau of Standards.

All analysed cations and anions in all the samples of groundwater from pits west of the hot spring, except sample W12, satisfy the standard of both WHO and Botswana Bureau of Standards Because of the existing concentration of $\mathrm{Na}^{+}, \mathrm{Cl}^{-}, \mathrm{Br}^{-}$and $\mathrm{SO}_{4}{ }^{2-}$, sample W12, hot spring water and all the samples of groundwater from the pits north of the hot spring do not satisfy the standard of both WHO and Botswana Bureau of Standards.

The analysed hot spring water and all the samples of groundwater from the pits north and west of the hot spring don't satisfy the standard of both WHOM and Botswana Bureau of Standards because of the existing concentration of $\mathrm{Ni}$ and $\mathrm{Pb}$ in the waters.

\section{Conclusions}

The hydrogeochemistry of any source of water is an important aspect of knowledge in order to address matters such as contamination and quality. In the analyzed water samples generally based on the mean values of the chemical parameters, the cations were in the order of abundance as $\mathrm{Na}^{+}>\mathrm{Ca}^{2+}>\mathrm{Mg}^{2+}>\mathrm{K}^{+}>\mathrm{Li}^{+}$and the anions were in the order of abundance as $\mathrm{Cl}^{-}>\mathrm{SO}_{4}{ }^{2-}>\mathrm{HCO}_{3}{ }^{-}>$ $\mathrm{PO}_{4}{ }^{3-}>\mathrm{Br}^{-}>\mathrm{CO}_{3}{ }^{2-}>\mathrm{NO}_{3}{ }^{-}>\mathrm{F}^{-}>\mathrm{NO}_{2}{ }^{-}$. In the analysed sediment samples the cations and anions are in the order of $\mathrm{Na}^{+}>\mathrm{Ca}^{2+}>\mathrm{K}^{+}>\mathrm{Mg}^{2+}>\mathrm{Li}^{+}$and $\mathrm{SO}_{4}{ }^{2-}>\mathrm{Cl}^{-}>\mathrm{NO}_{3}{ }^{-}>$ $\mathrm{Fl}^{-}>\mathrm{Br}^{-}>\mathrm{NO}_{2}{ }^{-}>\mathrm{PO}_{4}{ }^{3-}$, respectively. $75 \%$ the analyzed groundwater samples from the pits west of the hot spring show some similarities in the trend of concentration of the different constituents of the groundwater with the river water, suggesting that the groundwater is recent or derived from precipitation. A slight increment of values in the analyzed major cations, anions, and trace elements in the groundwater of this area is due to the dissolution of different minerals in the rocks of the study area. The remaining $25 \%$ the groundwater samples from this part of the study area suggest that precipitation is not the sole source of groundwater and it could be derived from both precipitation and fluids of deep origin.

The hot spring and the groundwater north of the hot springs are characterized by higher mineralization, and this could be attributed to the more supplement of the deep fluids that have deep origin. This implies that the source of the spring and the groundwater north of the hot spring have a regional origin.

The hot spring water and all groundwater in the studied area are not recommended for drinking purposes.

\section{Acknowledgements}

The authors duly acknowledge Office of Research and Development of University of Botswana for sponsoring this research work. 


\section{REFERENCES}

[1] Abreha, A G (2014) Hydrogeochemical and water quality investigation on irrigation and drinking water supplies in the Mekelle region, Northern Ethiopia University of Twente Faculty of Geo-Information and Earth Observation (ITC).

[2] Central Statistics Office (2009) Botswana water statistics, Department of Printing and Publishing Services, Gaborone.

[3] Todd, D K (1980) Groundwater Hydrology (second edition.) Wiley, New York

[4] Olivier, J., van Niekerk, H J and van der Walt I J (2008) Physical and chemical characteristics of thermal springs in the Waterberg area in Limpopo Province, South Africa Water S.A, April 2008.

[5] LaMoreaux P E and Tanner J T (Eds) (2001) Springs and bottled waters of the world Ancient History, Source, Occurrence, Quality and Use Springer.
[6] Johnson, M R., Vanvuuren, C J., Hegenberger, W F., Key, R \& Shoko, U (1996) Stratigraphy of the Karoo Supergroup in Southern Africa: an overview Journal of African Earth Sciences 23(1), 3-15 DOI 10.1016/S0899-5362(96)000486.

[7] Modie, B N., and Le Herisse, A (2009) Late Palaeozoic palynomorph assemblages from the Karoo Supergroup and their potential for biostratigraphic correlation, Kalahari Karoo Basin, Botswana Bulletin of Geosciences.

[8] Tahoora, S N., Mohammad, F R., Ahmad, Z A., Wan Nor, A S., Hafizan, J and Kazem, F., (2014) Identification of the Hydrogeochemical Processes in Groundwater Using Classic Integrated Geochemical Methods and Geostatistical Techniques, in Amol-Babol Plain, Iran The Scientific World Journal, vol 2014, Article ID 419058, p.15, doi:10.1155/2014/419058

[9] Botswana Bureau of Standards (2009) Drinking water specification BOS 32:2009 Second edition.

[10] World Health Organization (2003) Guidelines for Drinking Water Quality, Third Edition. 